\title{
Comparative Study of Cross Section Area Sizing Armatures Longitudinal Traction on Solid Slabs
}

\author{
Doriedson Sousa Dias', Charles Ribeiro de Brito², José Cláudio Moura Benevides ${ }^{3}$, Marco Antônio \\ Guerreiro Prado Filho ${ }^{4}$, José Roberto de Queiroz Abreu 5
}

\begin{abstract}
1,2,3,5 Laureate International Universities (UNINORTE). Av. Leonardo Malcher, 715 - Centro, Manaus - AM, CEP: 69010-060. Bairro: Centro. Manaus- Amazonas. Brazil. ${ }^{4}$ Universidade Federal do Pará (UFPA). Av. Augusto Correa 01.Guamá. Belém. Pará. Brazil. CEP: 66075-110. Caixa Postal 479. PABX +55 3201-7000.

Email: doriedsondias@gmail.com, marcoguerreiroprado@hotmail.com
\end{abstract}

Received: September $14^{\text {th }}, 2016$

Accepted: November, $10^{\text {th }}, 2016$

Published: December $22^{\text {th }}, 2016$

Copyright $@ 2016$ by authors and Institute of Technology Galileo of Amazon (ITEGAM) This work is licensed under the Creative Commons Attribution International License (CC BY 4.0).

http://creativecommons.org/licenses/by/4.0/ cc) (i)(2) Opea Acees:

\begin{abstract}
The development of structural project for buildings is of fundamental importance in the construction industry, given the fact that the buildings constructed under the provisions of a good project will surely meet the security, usability and economy. The construction is an economic activity that directly impacts on society as a whole, is of paramount importance that the professionals involved in the preparation of these projects are aware of the importance of the conception for excellent projects. This research aims to make the dimensioning sign of cross-sectional area of longitudinal tensile reinforcement $\left(A_{s}\right.$ and $\left.A_{s}^{\prime}\right)$ positive and negative, massive slabs of pavement coverage of a residential building, through two different methods (theoretical and computational). For this, the methodology applied in calculating these armors, we use the theory of Bares-Czerny, as well as the use of Eberick computational tool, keeping in mind the classical concepts of engineering and norms of the Brazilian Association of Technical Standards (ABNT). After completion of these calculations, we present results in tables and graphs and are held discussions in order to evaluate which method best suits the measurement of these armor and leads to the development of structural projects that result in the execution of a safe, rational, functional structure, economic and, most importantly, meets the United Limits Last (ULL) and United Services Limits (USL). With the completion of the discussion, we conclude that both methods meet the proposed objectives. However, using the computer program, it is possible to elaborate structural projects that minimize the loads applied on the building, will become more slender and therefore more economical, with dynamic and effective results. However, we emphasize that the program serves only to assist the engineer and not replace it. The tool that is now used does not have own intelligence, this being a designer attribute. That is, the fundamental concepts of structural analysis such as the equilibrium conditions, types of bonds, stateless and stability, among others, acquired with the field of dimensional theories, hence the importance of mastery of these theoretical concepts by the engineer.
\end{abstract}

Keywords: Structural Dimensioning. Bares-Czerny. Eberick. United Limits Last. United Services Limits.

\section{INTRODUCTION}

In the construction industry, to plan the construction of a building in Reinforced Concrete (RC), whether small, medium or large, it is important that the building is designed and executed given the current rules and laws of regulatory agencies and inspection. In this article, refers to the dimensioning of longitudinal reinforcement of positive and negative pull of the massive slabs of pavement covering an $\mathrm{RC}$ building as assumptions adopted for the proposed project, described later. The plain concrete is a material which has good resistance to compressive forces, but not to the tensile stress, thereby requiring add themselves more resistant materials (steel) constituted that bear the tensile stresses, becoming so simple concrete reinforced concrete.

Because the concrete present good resistance to compression, but no traction, the use of simple concrete had shown very limited. When resistance to compressive stress and traction is needed, is associated with materials which have high tensile 
strength, resulting in reinforced concrete (concrete and passive armor) or prestressed (concrete and active armor) [1].

Every building in RC must support the ULL and USL. For this, it is necessary that before starting the building process is designed structural design. Scale a reinforced concrete structure is to determine the concrete section (forms) and steel (armor) such that the structure does not collapse United Limits Last (ULL) or economic (state owner's pocket limit), their possible cracks are unobjectionable United Services Limits (USL), their arrows are not objectionable, provide good protection armor, preventing its corrosion, which could in the long run, lead to ruin the piece (coatings), the structure is poor, either because itself or by charging excess, it gives signs visible to the user, before reaching his ruin (warning condition), is durable [2].

In general, a good structural dimensioning ensures the conditions of use and security structure provided, meets in its entirety the steps of sizing, check and detailing. The aim of these three stages (design, verification, and detailing) which develops soon after the structural analysis is to ensure safety in relation to the United Limits Last (ULL) and United Services Limits (USL) of the structures as a whole, and each of its parts [3]. The main objective of this article is to make the design of the cross-sectional area of the longitudinal tensile reinforcement $\left(A_{s}\right.$ and $\left.A_{s}^{\prime}\right)$ positive and negative, of solid slabs cover floor of a residential building by two methods (theoretical and computational). And from the results, select best method is applied in the design and production of structural projects.

Therefore, it is applied two different methods of measurement $\left(A_{s}\right.$ and $\left.A_{s}^{\prime}\right)$. The first method, based on consecrated theories and principles of civil engineering. The slabs are structural elements responsible for transmitting the loads in them reach the beams, that the transfer of the pillars, which, in turn, lead foundations. They can be calculated as plates elastic regimes, which shows suitable for slabs subjected to service charges (verification of serviceability limit states), or hard-plastic, ideal for slab behavior observation break (check states ultimate limit) [1]. Usually, for the dimensioning of internal forces of the slabs, these are considered as plates in the elastic range. The positive reinforcement is responsible for absorbing the efforts of the positive bending moments, being located near the underside of the slab [...]. And, the negative reinforcement [...] is responsible for absorbing the efforts of the negative bending moments, being located near the upper side of the slab [1]. The slabs are flat elements, subject mainly to normal actions to your plan and concrete slabs are usually called slabs. [3]. The plates are twodimensional elements, where the thickness is much smaller than the other two dimensions (length and width). When made of concrete, these cards are called slabs. The charges received by slabs act in the direction perpendicular to its plane [1].

In this article, to refer sizing cross-sectional area of the reinforcement, it means that one should find the nominal diameter and nominal area of reinforcement used for the design of structural elements of the building. The nominal diameter is the value that is the equivalent diameter of the typical cross section of the wire or bar in millimeters and the nominal steel area, is the value that represents the cross-sectional area of the wire or specific nominal diameter bar, expressed in square millimeters. There are different types and armor gauges (steel) for construction of buildings. For the purposes of this standard, are classified as bars the nominal diameter of $6.3 \mathrm{~mm}$ or more products, obtained exclusively by hot rolling without further process of mechanical deformation. Classified as those threads of nominal diameter $10.0 \mathrm{~mm}$ or less, obtained from wire rod by drawing or cold rolling. According to the characteristic value of yield strength steel bars are classified in the CA-25 and CA-50 categories, and the steel wires in the CA-60 category [4].

For the second method of calculating $\left(A_{s}\right.$ and $\left.A_{s}^{\prime}\right)$ is used computational tool Eberick v9. Is available to the construction industry various CAD tools (Computer Aided Design) BIM (Building Information Modeling/Modeling of Information Construction) specific to the preparation of structural projects. Among these tools now, it cites the TQS, CYPECAD, Mscalc, Dlubal, Eberick, among others, help to specialist engineers to design accurate and excellent designs provided, apply the theoretical concepts and structural analysis fundamentals and the prescriptive requirements. Thus, well used, contribute to increased production and quality of projects. BIM is more than the modeling of a product, as it seeks to cover all aspects related to building [5].

The CAD software is classified as graphical tools supported by computer technology, whose goal is to develop designs and applied projects the most diverse areas of engineering, architecture, design, industrial design and visual communication, available commands and environments for imaging with high accuracy and static and dynamic visuals that allow the control of the development process of the steps of the project and minimize human errors [6].

The Eberick is a fully integrated system that allows the user within a multiwindow environment, access data of your project at any time. In this way, the whole project is loaded into memory (The Eberick, unlike other market programs, works with the concept of design instead of the current concept of working with isolated designs, so there is only one project that contains all data) [7].

The choice for the realization of this article is to highlight the importance and responsibility of the specialist engineers in structural projects has for the construction industry. Should the same, having deep knowledge of the subject, as well as the field of fundamental concepts of structural analysis and normative prescriptions that deal with projects, design and detailing of structures. Where, in addition to measurement of $\left(A_{s}\right.$ and $\left.A_{s}^{\prime}\right)$, it is realized the comparison of results obtained with application of the proposed methods in order to discuss, review and concluded that the best method is applicable to the structural calculation of armor. It is expected that the topics discussed here, contribute to improvement in the evolution of knowledge, serves as the basis for consultations, research and support material for technicians, technologists and future civil engineers, as well as contribute positively to social progress and technology in the formation of knowledge in our country.

\section{LITERATURE REVIEW}

In the conception of projects in civil engineering designers begin calculations grounded on three premises: security, economy and time (development of projects and execution of the work) [8]. For a correct measurement of slabs it is necessary to know all the internal forces that act on it. The internal forces and deformations in reinforced slabs in both directions can be determined by different theories, the most important being described as plates bending theory, developed based on the theory of elasticity, it allows efforts 
and arrows are determined any point of the slab; theory of grids; Approximate processes; Methods of weakening lines or plastic hinges; numerical methods such as the finite element analogy of the equivalent grid, finite difference methods [9].

The solution of the general equation of the plates is a very complex task, which led to the emergence of several tables from different sources and authors, with coefficients which provide the calculation of bending moments and arrows for specific cases supports and loads. There are several tables of authors like [9].

The building study of this article is small with a maximum elevation of $560 \mathrm{~cm}$ from the base of the ground to the top of it where the active dynamic pressure on the structure is small due to wind characteristic speed is low. Therefore, wind action will be disregarded. But we emphasize that, for very slender and high buildings, these actions should be considered. The characteristic wind speed is the speed of a burst of $3 \mathrm{~s}$ performed on average once in 50 years to $10 \mathrm{~m}$ above the ground and in the open plan [10].

In both methods of calculation applied in this article, the use analogies grids, which is a widely used method for analysis of slabs, easy to understand and produces satisfactory results. The analogy grid is a simple procedure which can be used satisfactorily for the calculation of forces and displacements slabs and building floors. In the particular case of slabs without beams floors, it has shown results consistent with other methods, sometimes even better. The method consists in replacing the plate (slab) by a corresponding mesh beams, each representing a given slab track, according to the dimension chosen for the mesh opening [11].

\section{MATERIALS AND METHODS}

\section{III.1 MEASUREMENT OF GENERAL MEASUREMENT GENERAL ASSUMPTIONS $\left(A_{S}\right.$ AND $A$ 's)}

For the development of this article, we adopt the quantitative method where, through the proposed dimensioning, we will make use of two different sizing methods, namely the use of Bares-Czerny theory and computational tool Eberick $v 9$, adopting the following assumptions:

a) Building on CA with baldrame floors, type 1 and cover with a ceiling height of $280 \mathrm{~cm}$, solid slabs, beams and columns with rectangular section $(20 \times 30) \mathrm{cm}$ and foundations on shoes.

b) Class Environmental Aggressiveness (CAA) II, described in Table 6.1 as [3]. Aggressiveness on the environment is related to physical and chemical actions that act on the concrete structures, regardless of mechanical actions, the volumetric variations of thermal origin, hydraulic retraction and others provided for in the design of structures [3].

c) Sealing walls in ceramic brick $9 \times 19 \times 19 \mathrm{~cm}$ without structural function, permissible voltage 150 Kilo Newton per Square Meter $\left(\mathrm{KN} / \mathrm{m}^{2}\right)$. The voltage adopted in design, applied to the ground by superficial foundation or base of the caisson, meets with predetermined safety factors, the ultimate limit states (rupture) and services (repressions, vibrations, etc.). This quantity is used when working with actions in characteristic values [12].

d) Strength Concrete Compressive Characteristic $\left(f_{c k}\right)$ of 25 Mega Pascals (MPa) in slabs, beams and columns and, in the shoes of $20 \mathrm{Mpa}$. In the case of $f_{c k}$ when not indicated age, strengths refer to age 28 days [3]. e) Steel armor CA-50. According to the characteristic value of yield strength steel bars are classified in the CA-25 and CA-50 categories, and the steel wires in the CA-60 category [4].

f) The armor coverings over the face of the element (c) of the slabs, meets the prescribed values in the table 7.2 in [3]. The minimum armor covering works is the lowest value that must be respected throughout the considered element. This constitutes acceptance criteria [3].

g) The density (PC) or specific weight of the materials used for the dimensioning of the building in study meets the values prescribed in table 1 in [12].

h) The accidental charges as prescribed in table 2 in [13]. Is all that it can act on the building structure according to their use (people, furniture, vehicles, and others) [13].

i) Thickness of slabs $1 \mathrm{~cm}$ cement mortar/sand and $1 \mathrm{~cm}$ in plaster at the bottom of the slab, taking into account the minimum and maximum thicknesses. Massive slabs must be respected for the following minimum thickness: $5 \mathrm{~cm}$ to cover slabs on the balance sheet; $7 \mathrm{~cm}$ for floor slabs or balance in coverage; $10 \mathrm{~cm}$ for slabs that support the total vehicle weight or less $30 \mathrm{kN} ; 12 \mathrm{~cm}$ for slabs that support the total weight of vehicles greater than $30 \mathrm{kN} ; 15 \mathrm{~cm}$ for slabs with prestressed beams supported, 1/42 for double floor slabs supported and 1/50 for continuous floor slabs, $16 \mathrm{~cm}$ to $14 \mathrm{~cm}$ flat slabs and slabs-for mushrooms [3]. Architecture with dimensions in centimeters, in the amount of $1120 \times 720$ in the directions of X and Y. And L1 600x300, L2 500x300, L3 600x400 and L4 500x400, 20x30 pillars $(b \times h)$, and beams with 20x30 ( $b w$ $\mathrm{x} h)$ as figure 1 .

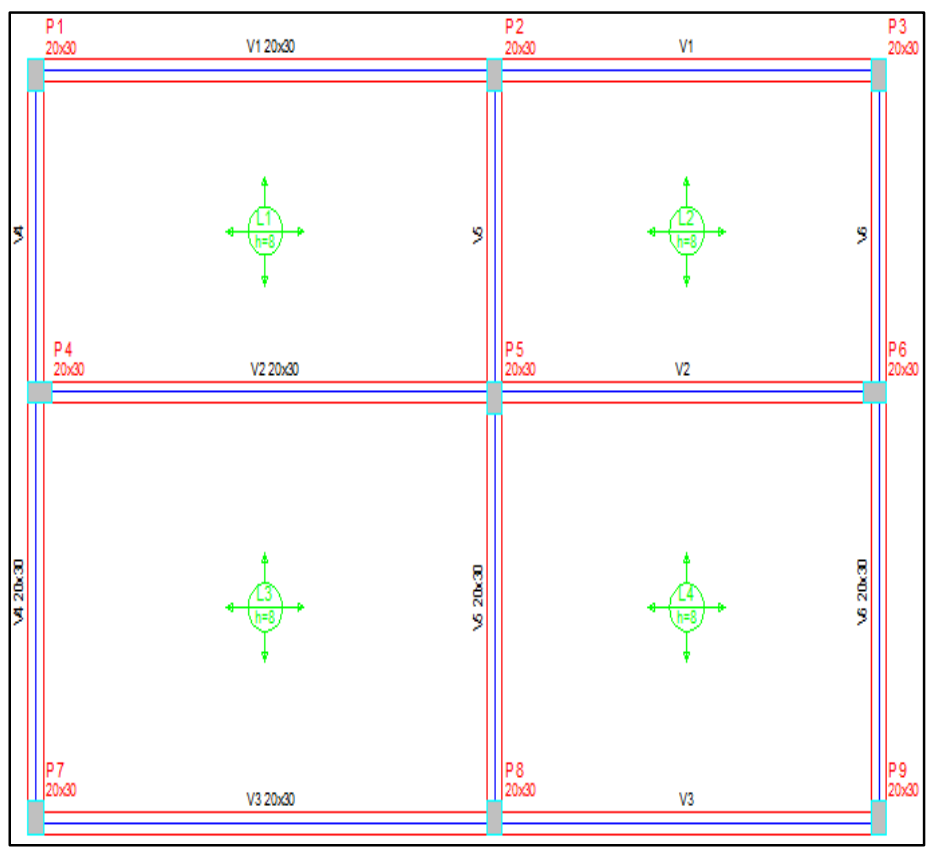

Figure 1. Floor plan covering the building.

Source: The authors, (2016).

\section{III.2 DIMENSIONING OF STEPS ( $A_{S}$ AND $A$ 's $)$ AS BARES- CZERNY THEORY}

Described in the figure 2 flowchart, the steps applied in sizing methodology $\left(A_{s}\right.$ and $\left.A_{s}^{\prime}\right)$ positive and negative proposed. 


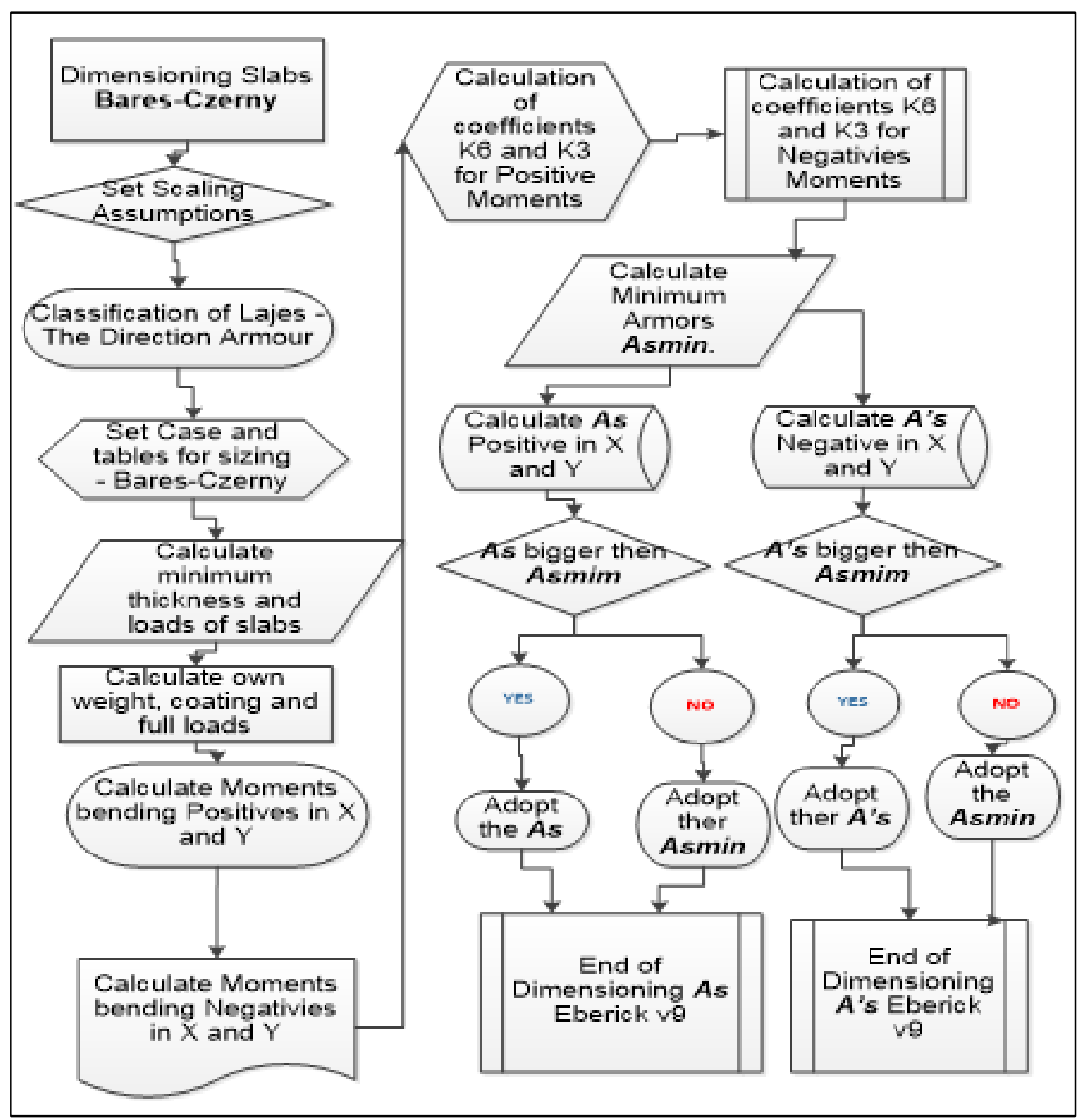

Figure 2: Flowchart of dimensioning $\left(A_{s}\right.$ and $\left.A_{s}^{\prime}\right)$ as Bares-Czerny theory. Source: The authors, (2016).

\section{III.3 THEORETICAL SCALING $\left(A_{S}\right.$ AND $A$ 's $)$}

For the theoretical measurement $\left(A_{s}\right.$ and $\left.A_{s}^{\prime}\right)$, in addition to the assumptions and prescriptive requirements adopted, we use classical methods based on elasticity theory that assumes that the material is homogeneous and isotropic and behave linearly.

The internal forces and deformations in reinforced slabs in both directions can be determined by different theories, the most important being described as plates bending theory, developed based on the theory of elasticity, it allows efforts and arrows are determined any point of the slab; theory of grids; Approximate processes; methods of weakening lines or plastic hinges; numerical methods such as the finite element analogy of the equivalent grid, finite difference methods [10].

The solution of the general equation of the plates is a very complex task, which led to the emergence of several tables from different sources and authors, with coefficients which provide the calculation of bending moments and arrows to cases specific supports and loads. There are several tables of [9] and [10].

\section{III.4 SCALING (As AND A's) AS BARES-CZERNY}

The Bares-Czerny process is nothing more than make the slab division by a grid of beams and applies appropriate coefficients that take into account precisely this aspect of the flagstones, full integrated joint solidarity of the whole mesh beams. The Bares-Czerny tables already make calculations directly, easily allowing the calculation of positive moments (allowing, after that, the calculation of reinforcement in the middle of the span) and negative (allowing, after that, the calculation of reinforcement in the support). For the calculation of $\left(A_{s}\right.$ and $\left.A_{s}^{\prime}\right)$, it is necessary to understand the symbology applied to the method as described in [1].

\section{III.5 SLABS RATING AS THE ARMATURES DIRECTIONS}

As Bares-Czerny theory, should be classified as slabs directions of armor. Before we proceed to calculate the slabs, we will divide them into two types, one for slabs whose width and length do not differ much, that is, where the larger does not exceed twice the other (which are the most common) and the other type for said rectangular slabs, in which one dimension is greater than twice 
the other. For the 1st case, we call the reinforced slabs in two directions (or reinforced slabs crosswise) and the other armed call in one direction [1]. That is, it is necessary to find the value of $\varepsilon$, which is the ratio between the values of the sides of $1 \mathrm{y} / \mathrm{lx}$ slab in order to classify the slab as the direction of armatures and define the coefficients for calculation of bending moments presented in [1], as shown in figure 3 .

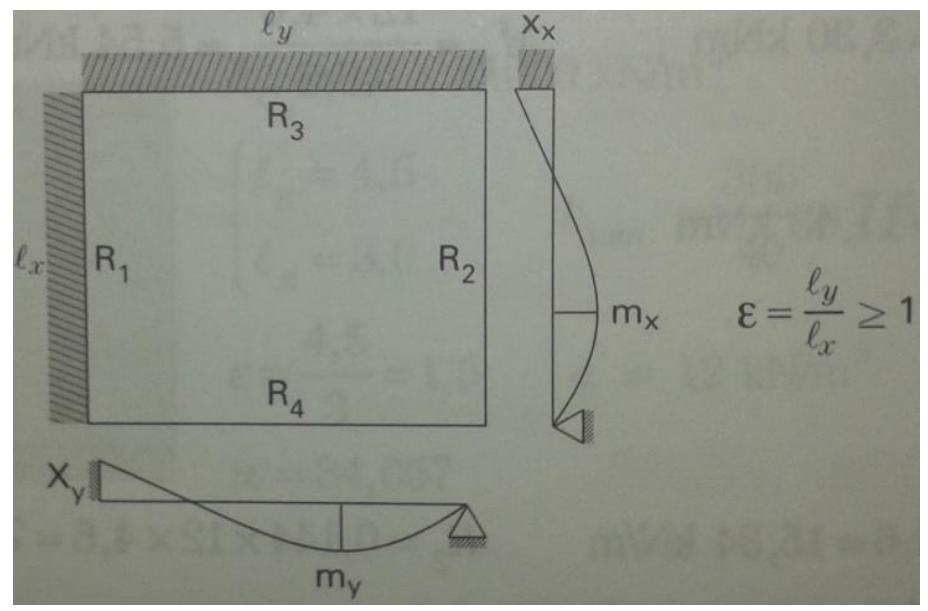

Figure 3: $\varepsilon$ ratio.

Source: [7].

\section{III.6 CLASSIFICATION OF SLABS AS FOR CASE - BARES- CZERNY THEORY}

According to theory Bares-Czerny, there are 6 types of cases for the dimensioning of solid slabs. Therefore, to know what type of case and which table to be used should check the type of cantilever of the edges (sides) of the slabs. In this work, all the slabs of the building are two edges (sides) continuous crimped. For we use the tables Bares-Czerny (reinforced slabs in both directions) must first check which of the six cases met; checking the case in which we find ourselves, we must guide the question of the axes. We calculate the ratio will be the only key entry, resulting known $\mathrm{mx}$, my, v1, v2, v3, v4; Knowing the mx, my, kx, ky can calculate $\mathrm{q}=$ total load $=$ live load + coating + own weight in $\mathrm{kN} / \mathrm{m}^{2}[1]$.

\section{III.7 CALCULATION OF SLABS MINIMUM THICKNESS}

In continuation, according theory Bares-Czerny, we must first calculate the minimum slab height $\left(h_{\min }\right)$. "[...] $h_{\min }=1 \mathrm{x} / 40$, practical criteria for determining the thickness of the slab, and $1 x$ the lower side [1].

\section{III.8 CALCULATION OF OWN WEIGHT OF COATINGS AND LOAD TOTAL SLABS}

For the measurement of $\left(A_{s}\right.$ and $\left.A_{s}^{\prime}\right)$ it is necessary to know the actual weight of the slabs, which is the product of the minimum height $\left(h_{\min }\right)$ by the specific gravity $(\rho \mathrm{c})$ of all materials (plaster, cement mortar/sand and RA used and specified in [1]. The own weight (pp) refers to the weight of the structural element, is found by the equation $\mathrm{p}=\mathrm{h} * \rho \mathrm{c}$ [1]. After finding the own weight of the materials used, perform the sum thereof, to further the total load to meet (q) of the slab [1].
For the total load the slabs should be considered all possible actions, such as self-weight, lower side of the slab flooring, subfloor (smoothing compound on the slab), walls, variable actions and all others that may exist. The result of the sum of the own weight of the materials found is the sum of all weights found themselves, namely: $\Sigma \mathrm{pp}=(\mathrm{pp}+\mathrm{pp}$ slab flooring cement mortar/sand + pp coating plaster), with the unit in $\mathrm{KN} / \mathrm{m}^{2}$, and the total charge (q) of the slab is obtained with equation $(q)=\{\Sigma p p+$ (q) \}, therefore, the sum of the own weight of the material ( $\Sigma$ pp) plus the load value accidental (qa) [1].

\section{III.9 CALCULATION OF BENDING MOMENTS IN POSITIVE DIRECTION X AND Y (MX AND MY)}

Still, according to Bares-Czerny theory, positive bending moments are needed to perform the sizing calculations of positive reinforcement $\left(A_{s}\right)$. Where, $\mathrm{Mx}$ and $\mathrm{My}$ are the positive bending moments that occur in the middle of the span. With the values $\mathrm{Mx}$, $\mathrm{My}$, and the thickness of the slab, it is possible to calculate the positive reinforcement (underside of the beam) in the $\mathrm{X}$ and $\mathrm{Y}$ direction [1].

We found the $M x$ value by equation $M x=q^{*} 1^{2} x / m x$ (positive moment in the middle of the span in the $\mathrm{X}$ direction considered in this case) and My value by equation $M y=q^{*} 1^{2} \mathrm{x} /$ my (positive moment in the middle of the span in the $\mathrm{Y}$ direction considered in the case). So to find the positive bending moments in the direction of $\mathrm{X}$ and $\mathrm{Y}$ of the slabs under study, we apply the equations $\mathrm{Mx}=\mathrm{q} * 1^{2} \mathrm{x} / \mathrm{mx}$ and $\mathrm{My}=\mathrm{q} * 1^{2} \mathrm{x} / \mathrm{my}$ respectively [1].

\section{III.10 CALCULATION OF NEGATIVE BENDING MOMENTS IN THE DIRECTION X AND Y (XX AND XY)}

In Bares-Czerny theory the negative bending moments are needed to perform the sizing calculations of negative reinforcement $\left(A_{s}^{\prime}\right)$, where $\mathrm{Xx}$ and $\mathrm{Xy}$ are negative bending moments that occur in the support in the $\mathrm{X}$ and $\mathrm{Y}$. These moments occur when this side and that toward the slab is crimped on another slab. With the values $\mathrm{Xx}, \mathrm{Xy}$, and the thickness of the slab, it is possible to calculate the negative reinforcement (upper face of the beam) in the direction $\mathrm{X}$ and $\mathrm{Y}[1]$.

We found the $X x$ value by equation $X x=q^{*} 1^{2} x / n x$ (negative moment in supporting the $\mathrm{X}$ direction considered in this case) and $X y$ value by equation $X y=q^{*} 1^{2} x / n y$ (negative moment in supporting the $\mathrm{Y}$ direction in the case considered). So to find the negative bending moments in the direction of $\mathrm{X}$ and $\mathrm{Y}$ all slabs study, we apply the equation $X x=q^{*} 1^{2} x / n x$ and $X y=q^{*} 1^{2} x / n y$ respectively [1].

\section{III.11 CALCULATION OF COEFFICIENTS K6 AND K3 FOR POSITIVE MOMENTS (MX AND MY)}

To find the cross-sectional area of longitudinal reinforcement of positive traction $\left(A_{s}\right)$, we calculate the coefficient K6 and later found the K3 coefficient. For this, we used T-10 table in [1]. The path will always be known the bending moment, calculate the K6 value by equation $\mathrm{K} 6=10^{5 *}\left[\left(\mathrm{~b} * \mathrm{~d}^{2}\right) / \mathrm{M}\right]$. For $\mathrm{b}=1$ $\mathrm{m}$ (calculation per meter) (range $1 \mathrm{~m} \mathrm{slab}$ ), $\mathrm{d}=$ distance from the compressed edge of the armor center of gravity $(\mathrm{m})$, where $\mathrm{d}=h_{\text {min }}$ - c), M=Moment positive bending in KN.m (Mx or My). Therefore, to find $\mathrm{K} 6$, apply the equations $\mathrm{K} 6 \mathrm{x}=10^{5 *}\left[\left(\mathrm{~d}^{2 * \mathrm{~b}}\right) / \mathrm{Mx}\right]$ and 
$\mathrm{K} 6 \mathrm{y}=10^{5 *}\left[\left(\mathrm{~d}^{2} * \mathrm{~b}\right) / \mathrm{My}\right]$ in the directions $\mathrm{X}$ and $\mathrm{Y}$ respectively. Where once we found the K6 values, knowing the concrete $f_{c k}$ and the type of steel to be used is the value of $\mathrm{K} 3$ as described in Table $\mathrm{T}-10$ in [1].

\section{III.12 CALCULATION OF K6 AND K3 COEFFICIENTS FOR NEGATIVE MOMENTS (XX AND XY)}

To find the cross-sectional area of longitudinal reinforcement of negative traction $\left(A_{s}^{\prime}\right)$, we calculate the coefficient K6 and then find the coefficient K3. For this, it uses the Table $\mathrm{T}-10$ in [1]. The path will always be known the bending moment, calculate the $\mathrm{K} 6$ value by equation $\mathrm{K} 6=10^{5 *}\left[\left(\mathrm{~b} * \mathrm{~d}^{2}\right) / \mathrm{X}\right]$. For $b=1 \mathrm{~m}$ (calculation per meter) (range $1 \mathrm{~m}$ slab), $\mathrm{d}=$ distance from the compressed edge of the armor center of gravity (m), where $\mathrm{d}=h_{\text {min }}-\mathrm{c}, \mathrm{M}=$ Moment negative bending in KN.m (Mx or My). Therefore, to find $\mathrm{K} 6$, apply the equations $\mathrm{K} 6 \mathrm{x}=10^{5 *}\left[\left(\mathrm{~d}^{2} * \mathrm{~b}\right) / \mathrm{Xx}\right]$ and $\mathrm{K} 6 \mathrm{y}=10^{5 *}\left[\left(\mathrm{~d}^{2} * \mathrm{~b}\right) / \mathrm{Xy}\right]$, in directions $\mathrm{X}$ and $\mathrm{Y}$ respectively. Where once found the K6 values, knowing the concrete $f_{c k}$ and the type of steel to be used, we found the value of $\mathrm{K} 3$ as described in Table T-10 in [1].

\section{III.13 CALCULATION OF SLABS MINIMUM ARMOR $\left(A_{S M I N}\right)$}

$A_{\text {smin }}$ is the minimum reinforcement adopted in the armor of the slabs if the result of the calculation of the main armor is below that value. So $A_{\text {smin }}$ is the minimum slab armor the main flexure, obtained by equation $A_{\text {smin }}=\rho \min * \mathrm{bw} * \mathrm{~h}$. Where $\rho \min =f_{c k}$ $0.15 \%$ to $20 \mathrm{MPa}, 25 \mathrm{MPa}$ and $30 \mathrm{MPa}, \quad b w=100 \mathrm{~cm}, h$ in $\mathrm{cm}$. Therefore, determining the values of $A_{\text {smin }}$ for all slabs applies the equation $A_{\text {smin }}=\rho \min * \mathrm{bw} * \mathrm{~h}[1]$.

\section{III.14 CALCULATION OF ( $A_{S}$ AND $A$ 's) AS BARES-CZERNY THEORY}

This is the calculation that serves the purpose of sizing $\left(A_{s}\right.$ and $\left.A_{s}^{\prime}\right)$ as theory Bares-Czerny. Where's is calculated by the equation $A_{s}=(\mathrm{K} 3 / 10)^{*}(\mathrm{M} / \mathrm{d})$, where $\mathrm{M}=(\mathrm{Mx}, \mathrm{My}, \mathrm{Xx}, \mathrm{Xy})$ already calculated, $\mathrm{K} 3=(\mathrm{K} 3 \mathrm{mx}, \mathrm{K} 3 \mathrm{my}, \mathrm{K} 3 \mathrm{Xx}, \mathrm{K} 3 \mathrm{Xy})$ has also calculated and $\mathrm{d}$ is the effective depth of the slab. To find the values of $\left(A_{s}\right)$ positive, we apply the equations $A_{s}=(\mathrm{K} 3 / 10)^{*}(\mathrm{Mx} / \mathrm{d})$ and $A_{s}=(\mathrm{K} 3 / 10)^{*}(\mathrm{My} / \mathrm{d})$ for the directions of $\mathrm{X}$ and $\mathrm{Y}$ respectively. And to find the values of $\left(A_{s}^{\prime}\right)$ negative apply the equations $A_{s}^{\prime}=(\mathrm{K} 3 / 10)^{*}(\mathrm{Xx} / \mathrm{d})$ and $A_{s}^{\prime}=(\mathrm{K} 3 / 10)^{*}(\mathrm{Xy} / \mathrm{d})$ for the directions of $\mathrm{X}$ and $\mathrm{Y}$ respectively [1].

\section{III.15 SCALING $\left(A_{S}\right.$ OR $A$ 's $)$ WITH EBERICK V9}

For the second sizing method $\left(A_{s}\right.$ and $\left.A_{s}^{\prime}\right)$ proposed and meet the flowchart of figure 4 . Where need initialize the program and create a project file to launch the structural elements of the building. For so much, we access the program tab in Project / New and create a new project file to launch the baldrame floors, type 1 and cover, as figure 5 .

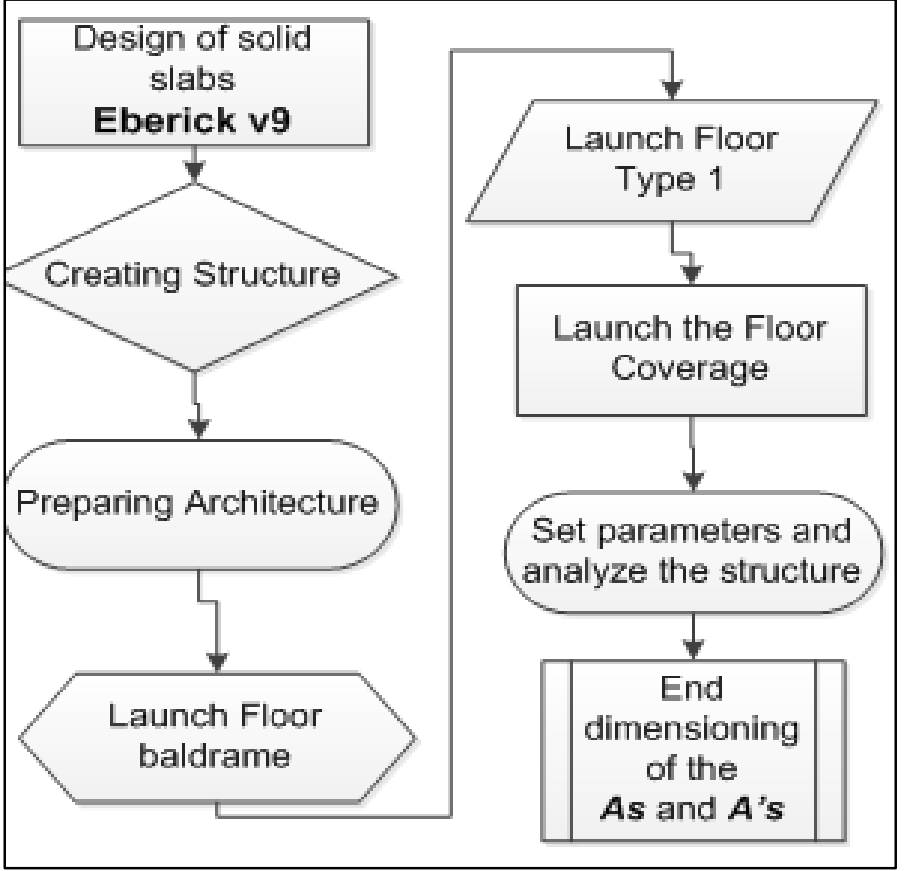

Figure 4: Flowchart summary of the dimensioning with Eberick $v 9$. Source: The authors, (2016).

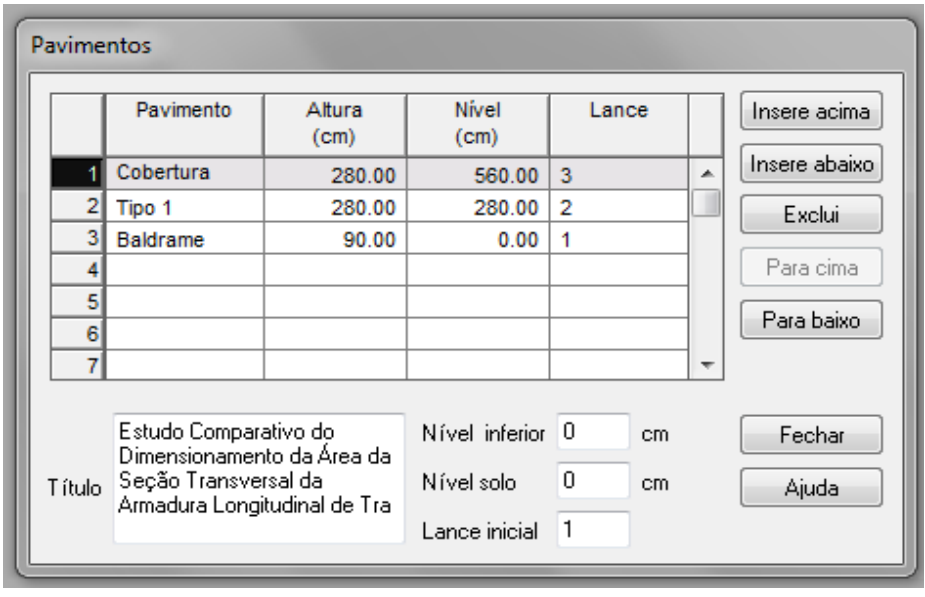

Figure 5: Project file creation to scale the structure.

Source: The authors, (2016).

\section{III.16 PREPARATION OF ARCHITECTURE}

For the launch of the structural elements (pillars, beams and slabs) of the building in Eberick $v 9$, first it is necessary to prepare the structure to receive the launch of the structural elements. Therefore, in the Project window, expands the pavement baldrame clicking (+) next to the name baldrame floor, to be open to the building architecture.

Then, it runs through double click on the sketch with the Architecture name, as figure 6. After opening up the sketch of the architecture, it is necessary to import (Tool, Read DWG/DXF) from an external file with extension .dxf, architecture in which will be held the launch of the structural elements of the study object of this structure work, as figure 7 . 


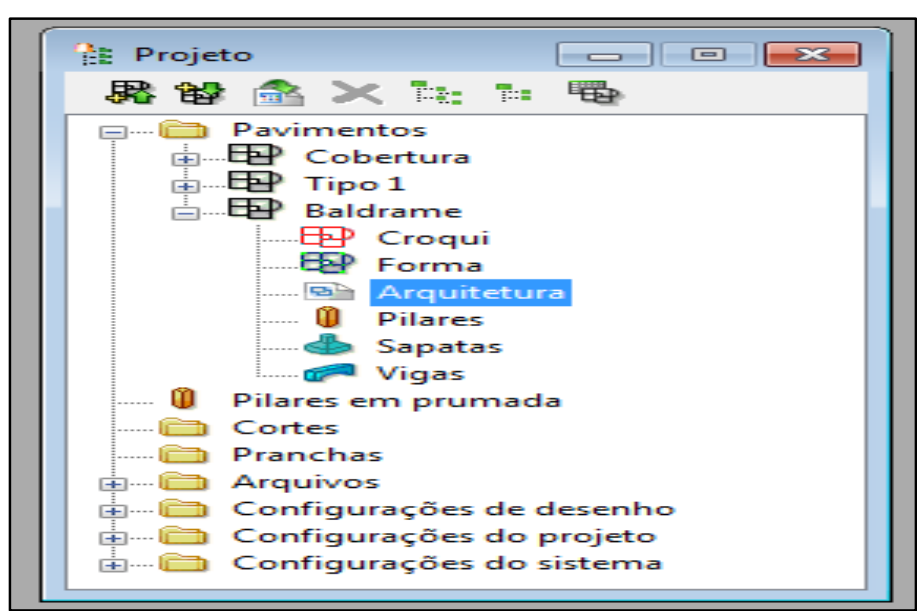

Figure 6: Architecture preparation.

Source: The authors, (21016).

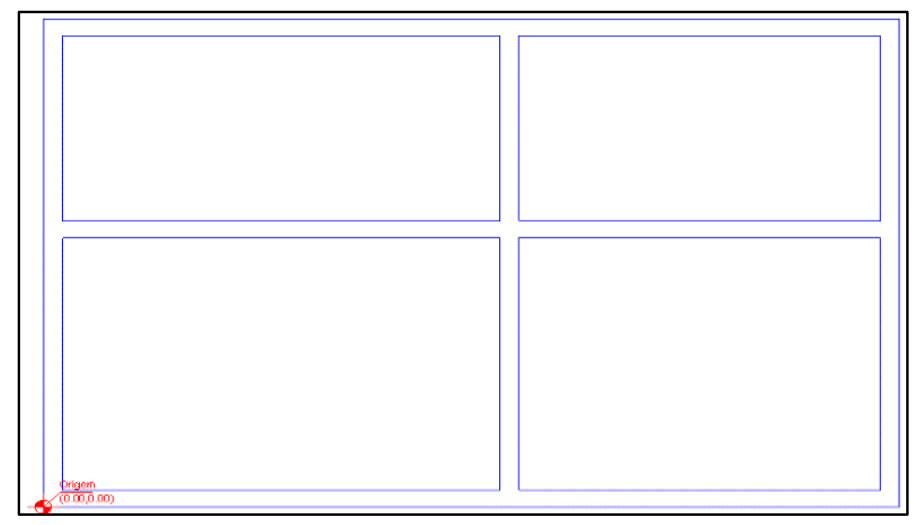

Figure 7: Architecture preparation.

Source: The authors, (2016).

\section{III.17 LAUNCH FLOOR BALDRAME}

This step is where takes place the launch of the pillars and beams on the pavement. Because it is the lower of the project deck does not launch slabs, we consider only one against inserted into the work floor.

\section{III.18 LAUNCH OF THE PILLARS}

Continuing the launch of the structural elements of the proposed building, it is necessary to achieve the release of all the pillars of baldrame floor, later to realize the launch of the beams. Therefore it is necessary to open the sketch of baldrame floor, by double-clicking the text baldrame in the project window. Thus opens the sketch baldrame floor window to carry out the launch of the pillars from the architectural plan of figure 8. With the sketch of the open baldrame floor, we perform a zoom on the launch area of the pillar P1 (top left architecture), as shown in figure 8. Next, we access the elements-Pillars menu and within this, we click Add. At the launch of the program dialog window pillars, are defined pillar of characteristics with rectangular section of $20 \times 30 \mathrm{~cm} \mathrm{(b} \mathrm{x}$ $\mathrm{h}$ ), and subsequently ends the launch of the column by clicking "OK", as shown in figure 8. To proceed with the release of the remaining pillars, performs the procedure adopted prior to the launch of the pillar P1.

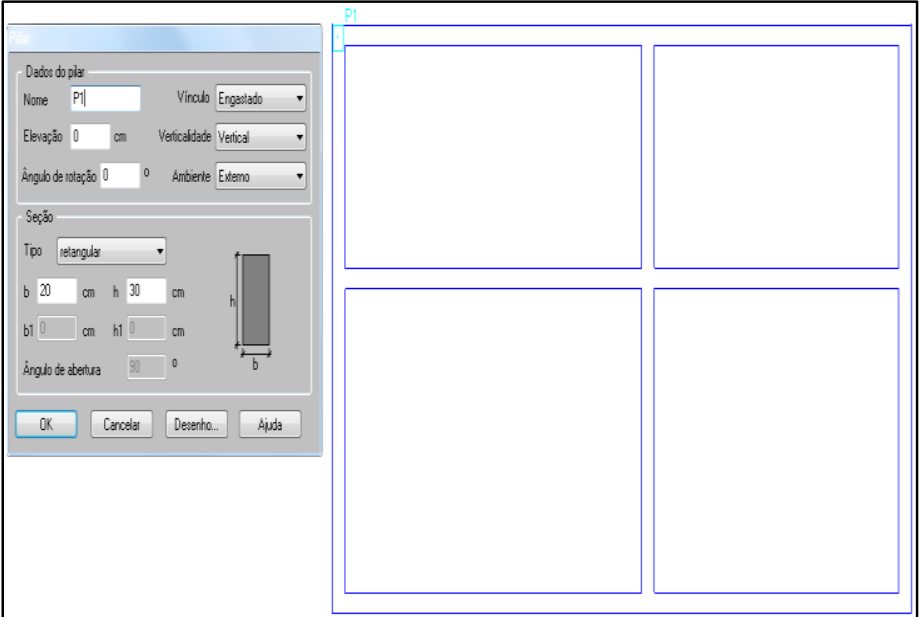

Figure 8: Architecture preparation.

Source: The authors, (2016).

\section{III.19 CONVERTER PILLARS FOUNDATION}

Continuing the launch of the structural elements of baldrame floor of the building, it is necessary to perform the conversion of all previously released pillars for foundation piles type shoes for the dimensioning of this work, was the kind of set foundation. Therefore, with the sketch of the open baldrame floor, accessed the Element command, Pillars/Convert to the foundation option, located in the program's command tab.

Subsequently, select up all pillars and pressed the enter key, aiming to open the window to choose the type of foundation that will be used for the project, as figure 9 .

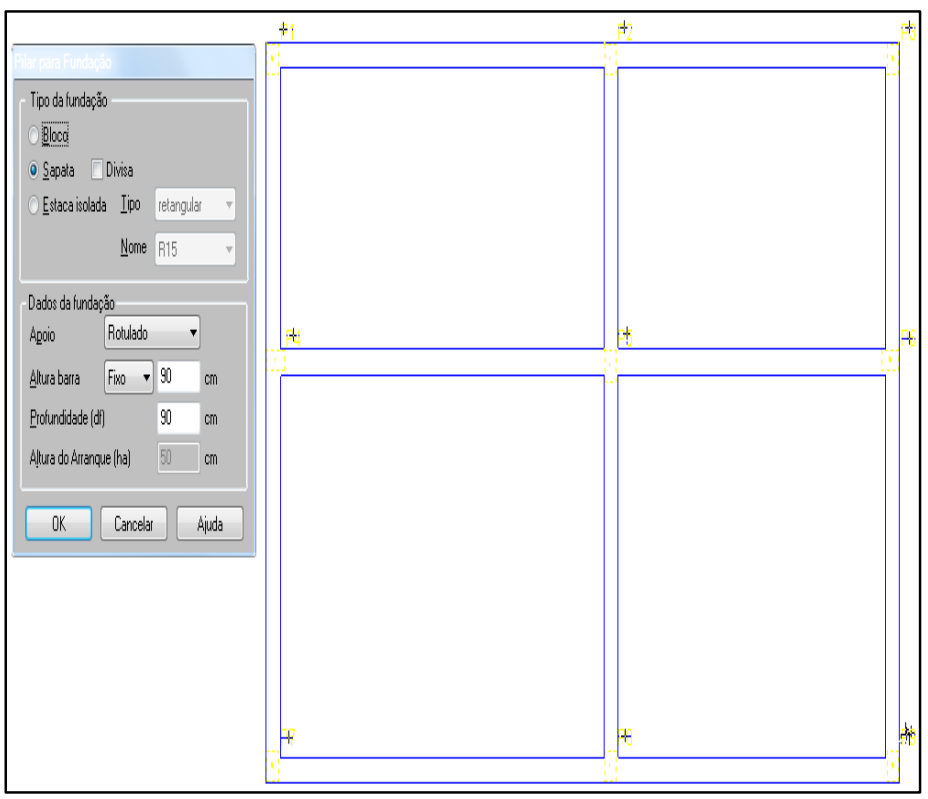

Figure 9: Converting the pillars of baldrame flooring shoes. Source: The authors, (2016).

After conversion of all pillars launched in baldrame pavement foundation for brand shoes, they have become in brand shoes foundations, as figure 10 . 


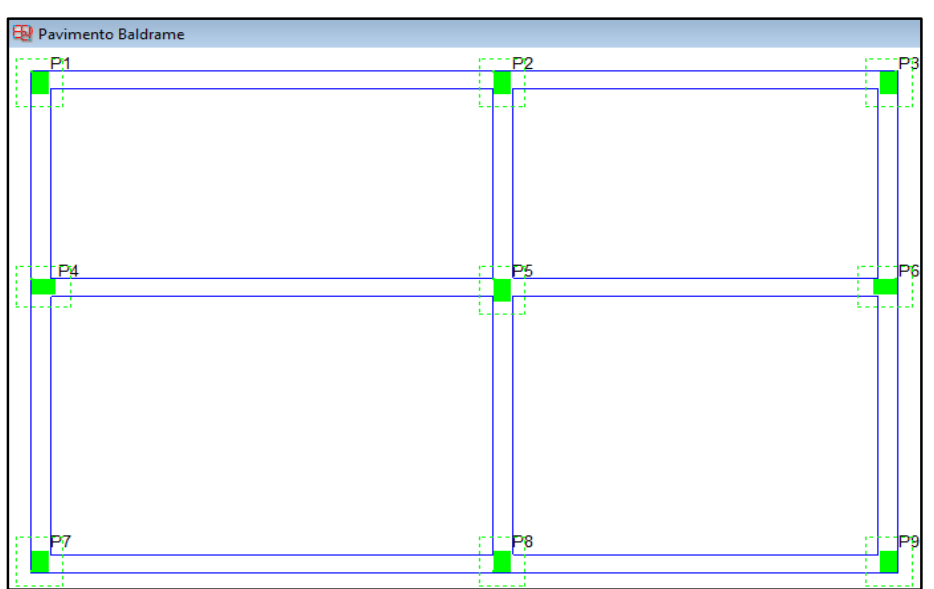

Figure 10: Pillars of baldrame floor converted to shoes.

Source: The authors, (2016).

\section{III.20 LAUNCH OF BEAMS}

Continuing the launch of the structural elements of baldrame floor, it is necessary to launch the beams in said floor. Therefore, it is necessary to open the sketch of baldrame floor by performing a double click on the baldrame text in the project window and, it displays the sketch of that floor to start the launch of the beams, as figure 11 .

With the sketch of the open baldrame floor, we launched the first beam (V1), on top of the architecture, with reference to the support of the P1 and P3 pillars. Therefore, access the Elementsbeams-Add menu beam to inform the characteristics of the cross section of the beams, as premises, is $20 \times 30 \mathrm{~cm}$ (b x h). In the Loads option-Wall, the we click on the "Launch" and inform the data for calculating the load of the walls on the beam. Wall with height and thickness of $250 \times 13 \mathrm{~cm}$ respectively and specific weight of 13 $\mathrm{kN} / \mathrm{m}^{3}$ for ceramic bricks as table 1 in [8]. After the above procedures, you select the portion of the beam corresponding to the range of $\mathrm{P} 1$ pillars $\mathrm{P} 3$, as shown in figure 11 .

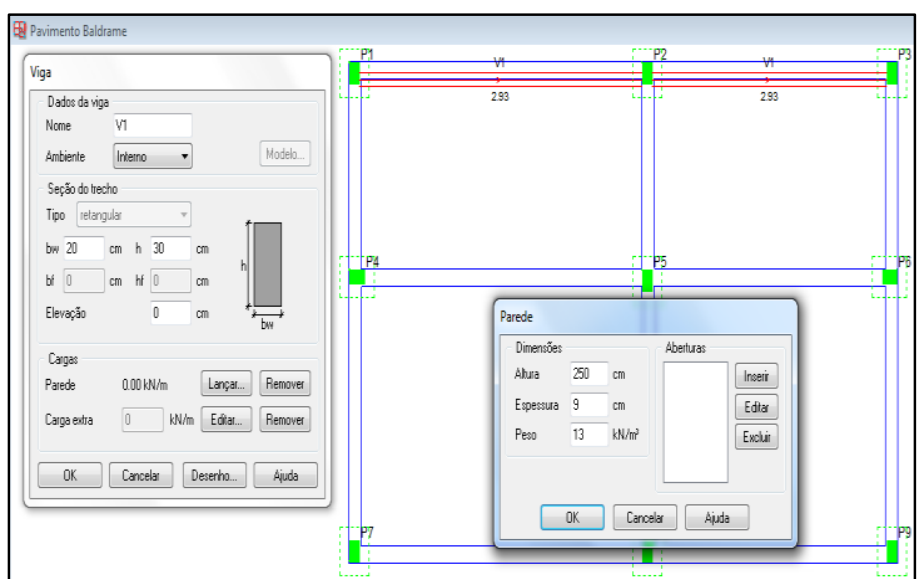

Figure 11: Launch of the baldrame floor beams.

Source: The authors, (2016).

\section{III.21 COPY SKETCH OF FLOOR BALDRAME FOR FLOOR TYPE 1}

After completion of the launch of the pillars and beams of baldrame floor, it is necessary to copy the sketch of the same for type 1 floor, through structure-Copy sketch command, as shown in figure 12. And with the completion of the launch of the pillars and beams of baldrame floors and type 1 , the structure is presented as figure 13 .

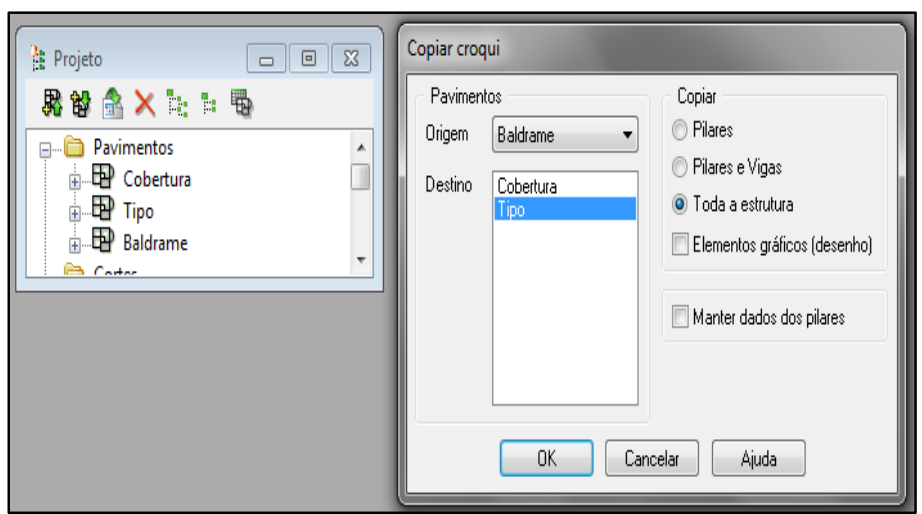

Figure 12: Copying the sketch of baldrame pavement to pavement type 1

Source: The authors, (2016).

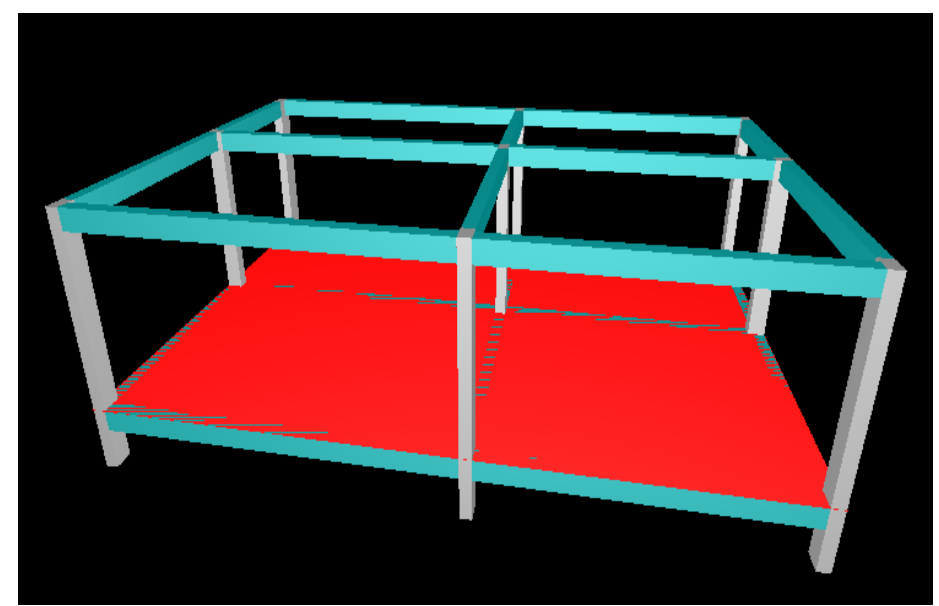

Figure 13: Final launch of the pillars and beams of baldrame and type flooring 1.

Source: The authors, (2016).

\section{III.22 FLOOR TYPE 1 LAUNCH}

Continuing the launch of the structural elements of the building proposed for the release of type 1 floor, only we launched the slabs, given that the pillars and beams were copied from baldrame pavement to type 1 pavement. This is necessary because the system scale the structure only after the full release of all structural elements that compose it.

\section{III.23 LAUNCH SLABS}

For the launch of the structural elements slabs, it is necessary to open the pavement sketch type 1. At this point perform a double click on the text type 1 , in the project window to display the sketch of that floor to begin the launch slabs as architectural plan of figure 14. In this work, as assumptions made, there was the launch of the massive slabs type in type 1 floor with access to the elements-lajes-Add menu. With the open slabs launch window, you define characteristics of the latter, with accidental 
load specification of $1.5 \mathrm{kN} / \mathrm{m}^{2}$ as table 2 in [8], coating load of $0.34 \mathrm{kN} / \mathrm{m}^{2}$ and initial thickness $8 \mathrm{~cm}$. After completion of the characteristics of the slabs, the program prompts the information "slab-point inside." At this point, click inside the outline of each slab defined by the floor support beams type 1, and then terminates the launch by pressing the Enter key, as shown in figure 15 .

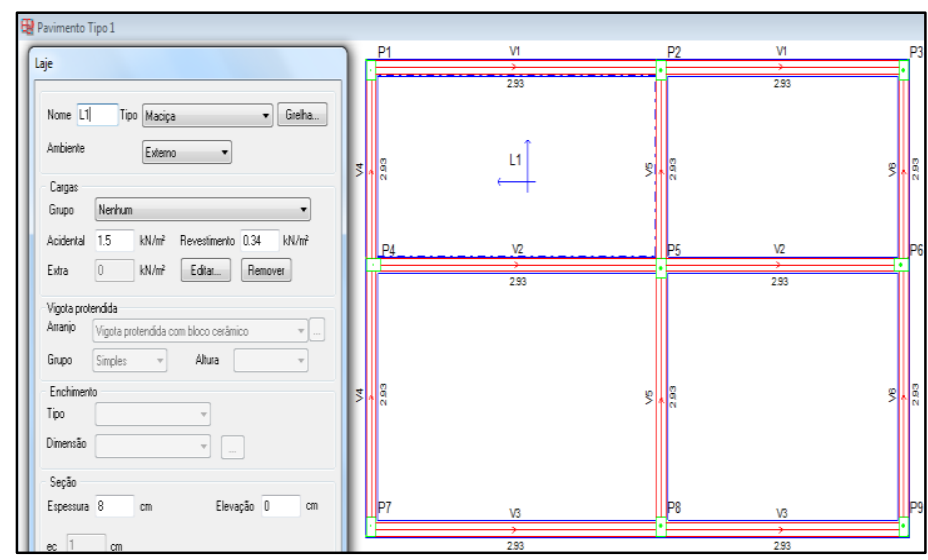

Figure 14: L1 slab release on pavement type 1.

Source: The authors, (2016).

With the completion of the release of all the slabs of pavement type 1, the structure is presented as figure 13 .

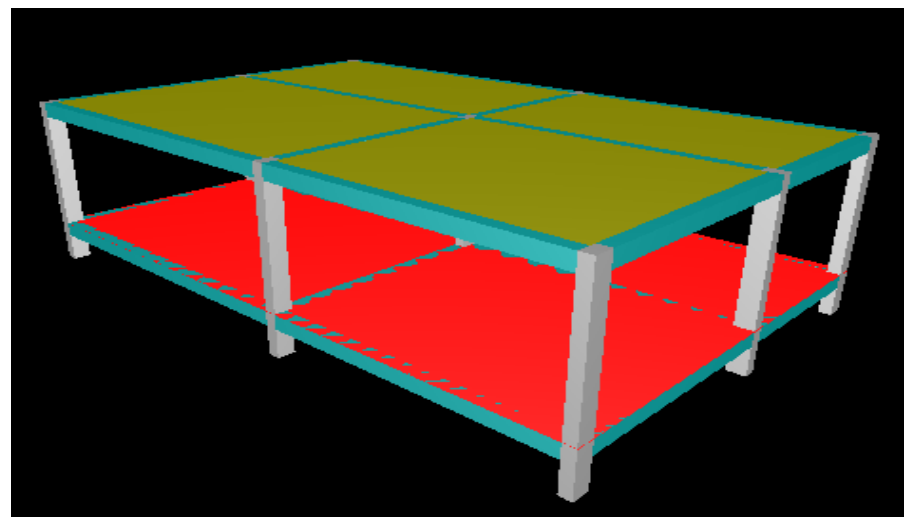

Figure 15: Type 1 floor structure after the release of the slabs. Source: The authors, (2016).

\section{III.24 LAUNCH OF FLOOR COVERING}

Continuing the launch of the structural elements of the proposed building, we move to launch the deck cover where it is necessary to carry out the copy of the type 1 floor sketch to the floor and make use of structure-Copy sketch command, as described above.

\section{III.25 REMOVAL OF THE FLOOR COVERING WALLS OF LOADS}

When we perform the copy of pavement type 1 for floor covering, loads of walls on the beams of the floor type 1, are automatically posted on the beams of the floor covering. However, the floor covering there are no walls on the beams. It will then be necessary to remove the charges from the walls of the joists of the floor covering.
Initially we access the sketch of the floor covering. After we open the sketch, we access the beam V1 by double-clicking on it and remove the loads from the walls of said beam. We must perform this procedure on all the beams of the floor covering, as shown in figure 16.

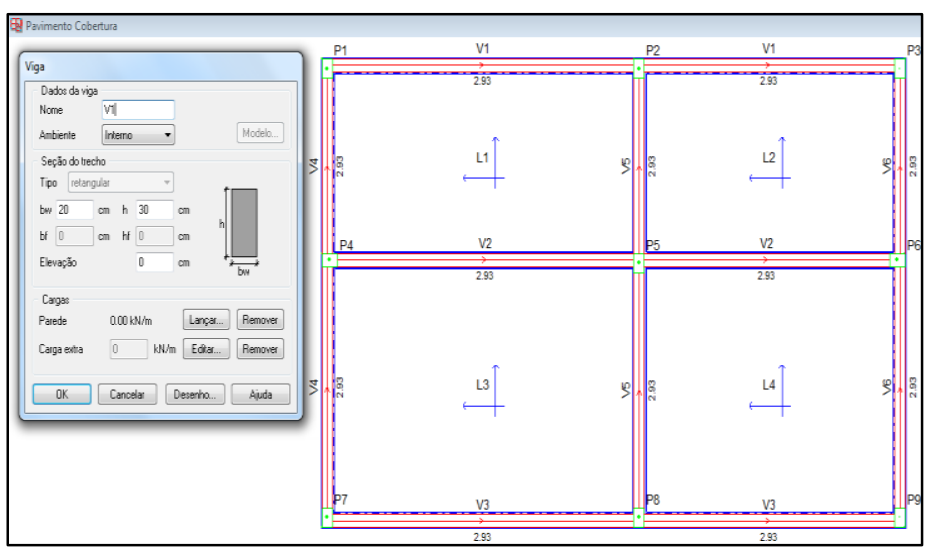

Figure 16: Removal of charges from the walls of the beams of the roof.

Source: The authors, (2016).

With the completion of the release of the slabs in the floor covering structure is presented ready for the realization of the structural sizing becomes a space frame with all the structural elements (pillars, beams and slabs) needed for the dimensioning of the building study released this monograph, and is presented as figure 17 .

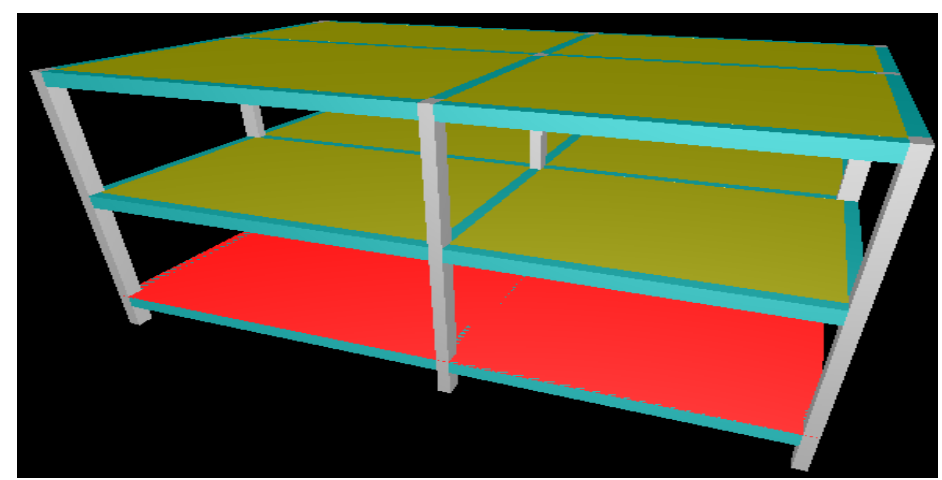

Figure 17: launch of the completion of the structure elements. Source: The authors, (2016).

\section{III.26 STRUCTURAL DIMENSIONING OF BUILDING ELEMENTS}

Continuing the proposed design, it is necessary before the structural dimensioning of the elements (slabs, beams, columns and shoes) of the construction study of this work, we make the settings of the necessary configuration elements which are dimensioning parameters in the program Eberick $v 9$, modes to meet the assumptions of dimensioning proposals.

Therefore, it was necessary we configure the Eberick $v 9$ CAA, $f_{c k}$ and the minimum concrete cover (c) of the structural elements of the building study of this work. There forever access the program command bar the item Settings-materials and durability, which define the parameters necessary for the dimensioning study, as figures 18 and 19. 


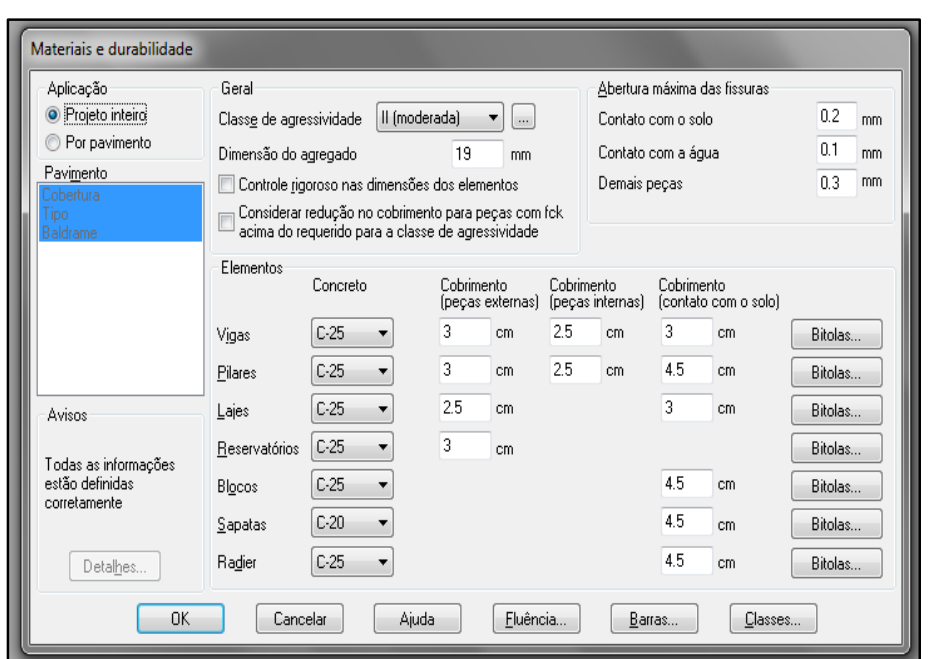

Figure 18: Configuring CAA, $f_{c k}$ and coatings (c).

Source: The authors, (2016).

\begin{tabular}{|c|c|c|c|c|c|c|c|c|c|c|c|}
\hline \multicolumn{12}{|c|}{ Armadura } \\
\hline & Bitola & Ativa & \multicolumn{2}{|c|}{ Aço } & \multicolumn{2}{|c|}{ Fabricação } & \multirow{2}{*}{\begin{tabular}{|c|}
$\begin{array}{c}\text { Comprimento } \\
(\mathrm{cm})\end{array}$ \\
1200.00 \\
\end{tabular}} & \multirow{2}{*}{\begin{tabular}{|r|} 
Peso do rolo $(\mathrm{kg})$ \\
170
\end{tabular}} & \multicolumn{3}{|l|}{ Emenda } \\
\hline & 3.2 & v & CA60 & 7 & rolo & 17 & & & nenhuma & & $A$ \\
\hline 2 & 3.4 & $\sqrt{v}$ & CA60 & 7 & rolo & Fi & 1200.00 & 170 & nenhuma & & \\
\hline 3 & 4.0 & V & CA60 & 7 & rolo & 17 & 1200.00 & 170 & nenhuma & & \\
\hline 4 & 4.2 & v & CA60 & 7 & rolo & 17 & 1200.00 & 170 & nenhuma & & \\
\hline 5 & 4.6 & v & CA60 & 7 & rolo & 17 & 1200.00 & 170 & nenhuma & & \\
\hline 6 & 5.0 & $\sqrt{2}$ & CA60 & 7 & rolo & 17 & 1200.00 & 170 & nenhuma & & \\
\hline 7 & 6.0 & $\sqrt{2}$ & CA60 & 7 & rolo & 17 & 1200.00 & 170 & nenhuma & & \\
\hline 8 & 6.3 & $\sqrt{2}$ & CA50 & 7 & barra & 17 & 1200.00 & 0 & traspasse & 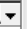 & \\
\hline 9 & 7.0 & $\sqrt{v}$ & CA60 & 7 & rolo & 17 & 1200.00 & 170 & nenhuma & & \\
\hline 10 & 8.0 & $\sqrt{\mathrm{v}}$ & CA50 & 7 & barra & 17 & 1200.00 & 0 & traspasse & $\pi$ & \\
\hline 11 & 10.0 & $\sqrt{v}$ & CA50 & 7 & barra & 7 & 1200.00 & 0 & traspasse & 1 & \\
\hline 12 & 12.5 & $\sqrt{v}$ & CA50 & 7 & barra & 17 & 1200.00 & 0 & traspasse & $\pi$ & \\
\hline 13 & 16.0 & $\sqrt{2}$ & CA50 & 7 & barra & 7 & 1200.00 & 0 & traspasse & $\nabla$ & \\
\hline 14 & 20.0 & V & CA50 & 7 & barra & 7 & 1200.00 & 0 & traspasse & $\nabla$ & \\
\hline 15 & 22.2 & $\sqrt{2}$ & CA50 & 7 & barra & 17 & 1200.00 & 0 & traspasse & $\pi$ & \\
\hline 16 & 25.0 & v & CA50 & 7 & barra & 7 & 1200.00 & 0 & traspasse & 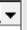 & \\
\hline 17 & 32.0 & $\sqrt{v}$ & CA50 & $\nabla$ & barra & 7 & 1200.00 & 0 & solda & & - \\
\hline & & & & DK & & incela & Aiuda & & & & \\
\hline
\end{tabular}

Figure 19: Configuration of the steel used in sizing.

Source: The authors, (2016).

\section{III.27 STRUCTURE PROCESSING}

With the completion of the processing of the structure, object of this work, we serve the proposed dimensioning, whose specific aim is to scale the cross-sectional area of longitudinal tensile reinforcement $\left(A_{s}\right.$ and $\left.A_{s}^{\prime}\right)$ positive and negative of the slabs of the proposed building using the computational tool CAD BIM Eberick $v 9$.

After finalizing the release of all structural elements and settings of dimensioning parameters in Eberick $v 9$ tool, it is necessary to carry out the validation processing structure for the program. It is at this stage that the program evaluates and structurally scales all elements (slabs, beams, columns and shoes) of the building. That is, checks the overall stability of the structure, calculating the bending moments, torsional, sharp, arrows, scroll, etc. For this purpose, we access the program command menu structure-Processing structure and pressed the $\mathrm{OK}$ option, as figures 20 to 21 .

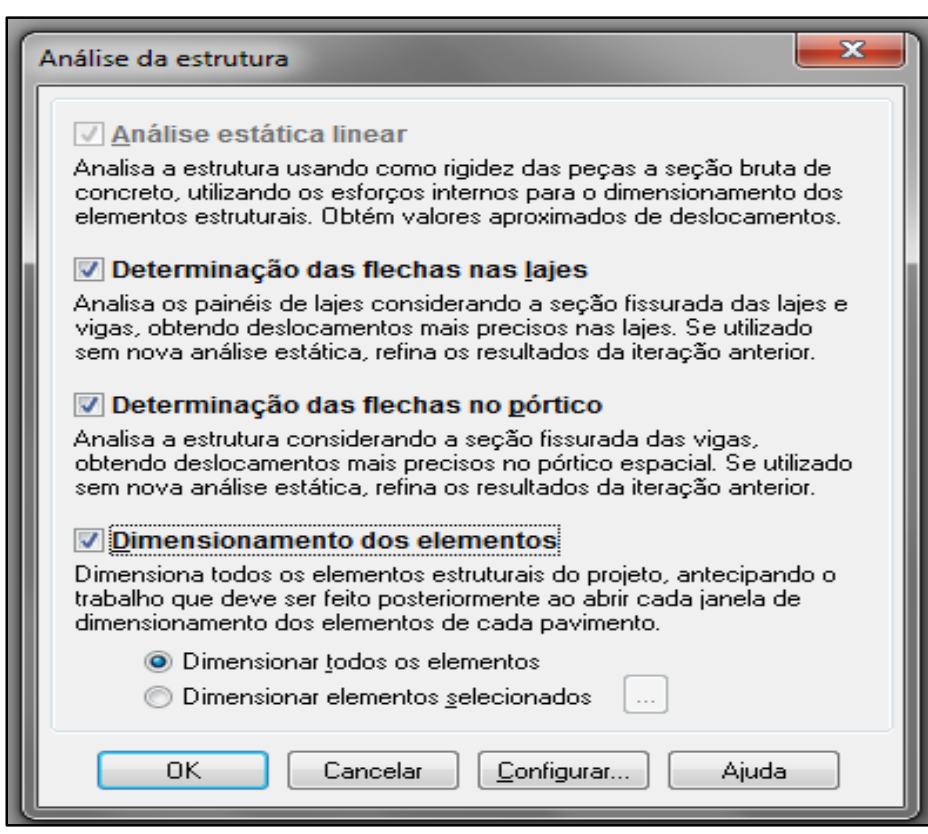

Figure 20: Design and/or structural analysis of the building. Source: The authors, (2016).

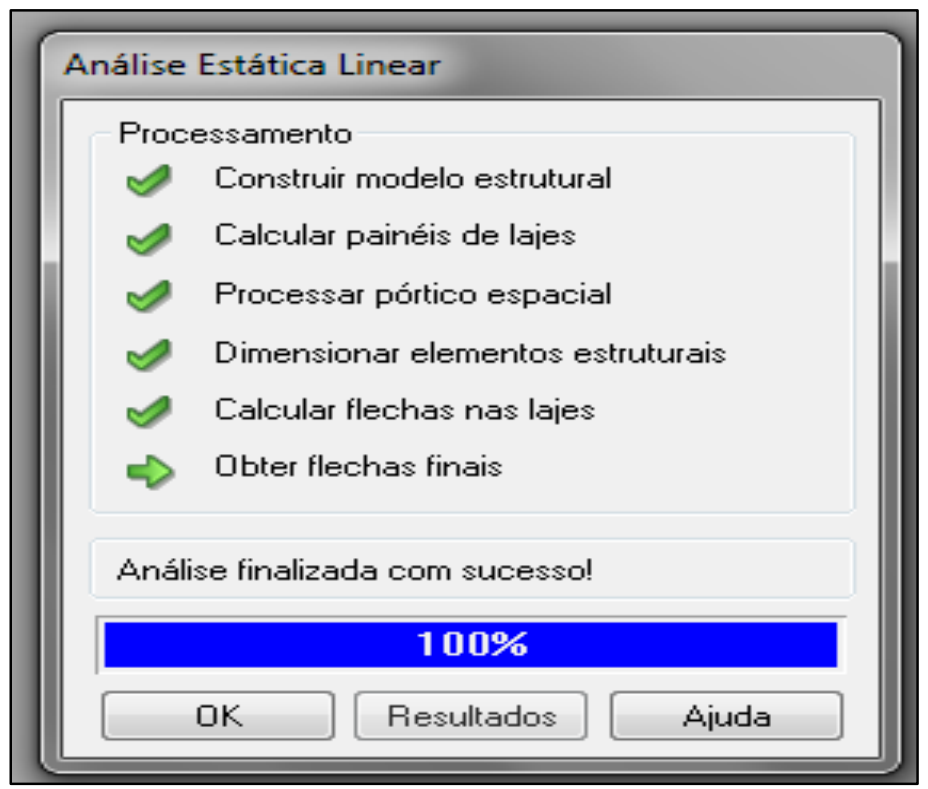

Figure 21: Structural Dimensioning finalized. Source:

The authors, (2016).

\section{RESULTS AND DISCUSSIONS}

\section{IV.1 ADOPTED RESULTS OF $H_{M I N}$, OWN WEIGHT AND SLABS LOAD}

With the application of the methods of sizing $\left(A_{s}\right.$ and $\left.A_{s}^{\prime}\right)$ proposed in this paper, we obtained resulting values for minimum height $\left(h_{\min }\right)$, own weight slabs and coatings, as well as the total charge (q), as shown in the table 1 and graphs the figure 22 to 23. Based on these results, we evaluated the differences thereof with respect to the application of the measurement methods used in order to be made the necessary discussion of the data. 
Table 1: hmin results, own weight and loads of slabs.

\begin{tabular}{|c|c|c|c|c|c|c|}
\hline \multicolumn{7}{|c|}{ Results Bares-Czerny Theory and Eberick $v 9$} \\
\hline Slabs & $\begin{array}{l}\mathrm{h}(\mathrm{cm}) \\
\text { Bares- } \\
\text { Czerny }\end{array}$ & $\begin{array}{c}\mathrm{h}(\mathrm{cm}) \\
\text { Eberick } \\
\text { v9 }\end{array}$ & $\begin{array}{c}\mathrm{Pp} \\
\mathrm{KN} / \mathrm{m}^{2} \\
\text { Bares- } \\
\text { Czerny }\end{array}$ & $\begin{array}{c}\mathrm{Pp} \\
\mathrm{N} / \mathrm{m}^{2} \\
\text { Eberick } \\
v 9\end{array}$ & $\begin{array}{c}\mathrm{q} \\
\mathrm{KN} / \mathrm{m}^{2} \\
\text { Bares- } \\
\text { Czerny }\end{array}$ & $\begin{array}{c}\mathrm{q} \\
\mathrm{KN} / \mathrm{m}^{2} \\
\text { Eberick } \\
v 9\end{array}$ \\
\hline L1 & 10 & 8 & 2,5 & 2 & 4,34 & 3,84 \\
\hline L2 & 10 & 8 & 2,5 & 2 & 4,34 & 3,84 \\
\hline L3 & 10 & 8 & 2,5 & 2 & 4,34 & 3,84 \\
\hline $\mathrm{L} 4$ & 10 & 8 & 2,5 & 2 & 4,34 & 3,84 \\
\hline
\end{tabular}

Source: The authors, (2016).

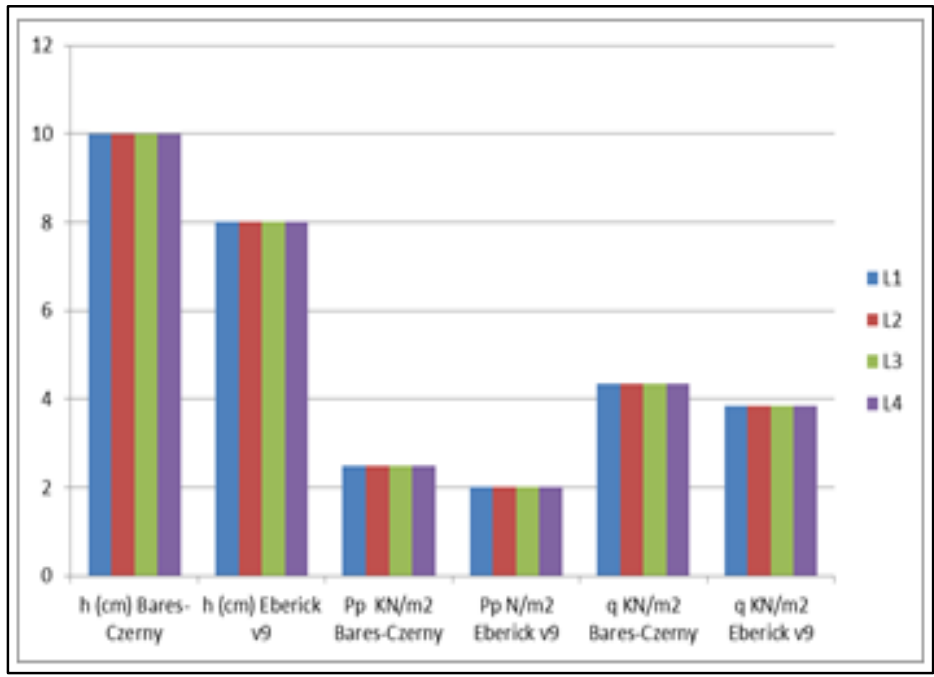

Figure 22. Chart : $h_{\min }$ chart, own weight and loads of slabs. Source: The authors, (2016).

Subsequently we present the reduction of the minimum height percentage $\left(h_{\min }\right)$ of the slabs and loads applied to the structure, as shown in table 2 to figure 23 to be evaluated and discussed.

Table 2: Comparison of minimum heights (h) and loads (q) adopted between Eberick $v 9$ and Bares-Czerny.

\begin{tabular}{|c|c|c|c|c|c|c|}
\hline \multicolumn{7}{|c|}{ Reduction of heights and loads of slabs } \\
\hline \multirow{2}{*}{$\begin{array}{c}\text { Slabs } \\
\text { Slabs }\end{array}$} & \multicolumn{2}{|c|}{ Bares-Czerny } & \multicolumn{2}{|c|}{ Eberick v9 } & \multicolumn{2}{|c|}{$\begin{array}{l}\text { Reduction with use } \\
\text { of Eberick } v 9\end{array}$} \\
\hline & $\begin{array}{c}h \\
(\mathrm{~cm})\end{array}$ & $\begin{array}{c}q \\
\mathrm{KN} / \mathrm{m}^{2}\end{array}$ & $\begin{array}{c}h \\
(\mathbf{c m})\end{array}$ & $\begin{array}{c}q \\
\mathrm{KN} / \mathrm{m}^{2}\end{array}$ & $h(\%)$ & $q(\%)$ \\
\hline L1 & 10 & 4,34 & 8 & 3,84 & $-20.00 \%$ & $-11.52 \%$ \\
\hline $\mathbf{L} 2$ & 10 & 4,34 & 8 & 3,84 & $-20.00 \%$ & $-11.52 \%$ \\
\hline $\mathbf{L 3}$ & 10 & 4,34 & 8 & 3,84 & $-20.00 \%$ & $-11.52 \%$ \\
\hline L4 & 10 & 4,34 & 8 & 3,84 & $-20.00 \%$ & $-11.52 \%$ \\
\hline
\end{tabular}

Source: The authors, (2016).

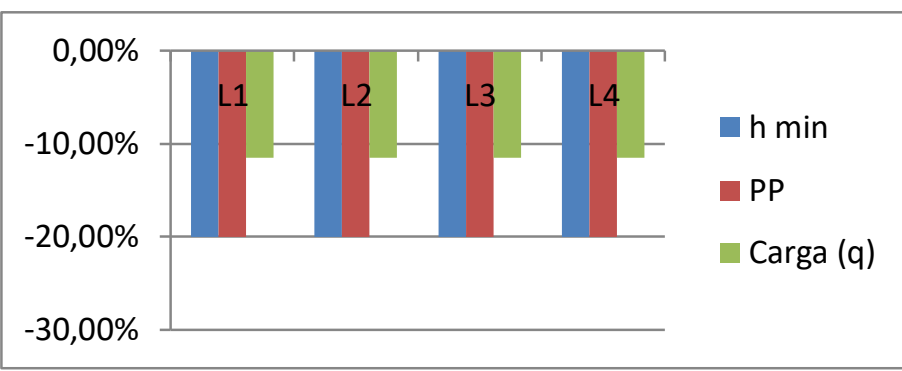

Figure 23. Chart : \% Reduction in height (h) and loads (q) between Eberick $v 9$ and Bares-Czerny.

Source: The authors, (2016).

\section{IV.2 RESULTS $\left(A_{S}\right)$ OF SLABS IN X AND Y AS BARES- CZERNY AND EBERICK $V 9$}

Continuing the presentation of the results obtained by applying the methods for sizing through Bares-Czerny theory and Eberick $v 9$, we present the final results (As) in the $\mathrm{X}$ and $\mathrm{Y}$ directions for both methods adopted, as described in Table 3 and graphs the figure 24 to 27 . Thus, this information will provide subsidies for the implementation of further analysis and discussions.

Table 3: Sizing results and/or structural analysis of the building.

\begin{tabular}{|c|c|c|c|c|c|c|}
\hline \multicolumn{7}{|c|}{ Results $A_{s x}$ and $A_{s y}$ for sizing of the slabs as Bares-Czerny Theory } \\
\hline \multirow{2}{*}{ Slabs } & $h_{m i m}$ & $\mathbf{q}$ & $\operatorname{Mdx}$ & Mdy & $\begin{array}{l}A_{\text {sx } x, c a l} \\
\mathbf{c m}^{2} / \mathbf{m}\end{array}$ & $\begin{array}{l}A_{\text {sy,cal }} \\
\mathrm{cm}^{2} / \mathbf{m}\end{array}$ \\
\hline & $(\mathrm{cm})$ & $\mathrm{kN} / \mathrm{m}^{2}$ & $\mathbf{k N} \cdot \mathbf{m} / \mathbf{m}$ & $\mathrm{kN} \cdot \mathrm{m} / \mathrm{m}$ & $\begin{array}{l}A_{s x}, a d o \\
\mathrm{~cm}^{2} / \mathbf{m}\end{array}$ & $\begin{array}{l}A_{s y, a d o} \\
\mathrm{~cm}^{2} / \mathbf{m}\end{array}$ \\
\hline \multirow{2}{*}{ L1 } & \multirow{2}{*}{10} & \multirow{2}{*}{4.34} & \multirow{2}{*}{2.28} & \multirow{2}{*}{0.648} & $A_{s}=0.96$ & $A_{s}=0.28$ \\
\hline & & & & & $A_{s}=1.54$ & $A_{s}=1.54$ \\
\hline \multirow{2}{*}{$\mathrm{L} 2$} & \multirow{2}{*}{10} & \multirow{2}{*}{4.34} & \multirow{2}{*}{1.97} & \multirow{2}{*}{0.689} & $A_{s}=0.86$ & $A_{s}=0.30$ \\
\hline & & & & & $A_{s}=1.54$ & $A_{s}=1.54$ \\
\hline \multirow{2}{*}{ L3 } & \multirow{2}{*}{10} & \multirow{2}{*}{4.34} & \multirow{2}{*}{3.12} & \multirow{2}{*}{1.31} & $A_{s}=1.37$ & $A_{s}=0.57$ \\
\hline & & & & & $A_{s}=1.50$ & $A_{s}=1.50$ \\
\hline \multirow{2}{*}{$\mathrm{L} 4$} & \multirow{2}{*}{10} & \multirow{2}{*}{4.34} & \multirow{2}{*}{2.62} & \multirow{2}{*}{1.45} & $A_{s}=1.15$ & $A_{s}=0.63$ \\
\hline & & & & & $A_{s}=1.50$ & $A_{s}=1.54$ \\
\hline \multicolumn{7}{|c|}{ Results $A_{s x} e A_{s y}$ for sizing of the slabs as Eberick $v 9$} \\
\hline \multirow{2}{*}{ Slabs } & $h_{\text {mim }}$ & (q) & Mdx & Mdy & $\begin{array}{l}A_{\text {sx, cal }} \\
\mathbf{c m}^{2} / \mathbf{m}\end{array}$ & $\begin{array}{c}A_{\text {sy,cal }} \\
\mathrm{cm}^{2} / \mathrm{m}\end{array}$ \\
\hline & $(\mathrm{cm})$ & $\mathbf{k N} / \mathbf{m}^{2}$ & $\mathbf{k N} . \mathbf{m} / \mathbf{m}$ & $\mathbf{k N} . \mathbf{m} / \mathbf{m}$ & $\begin{array}{l}A_{s x, a d o} \\
\mathbf{c m}^{2} / \mathbf{m}\end{array}$ & $\begin{array}{l}A_{s y, a d o} \\
\mathbf{c m}^{2} / \mathbf{m}\end{array}$ \\
\hline \multirow{2}{*}{ L1 } & \multirow{2}{*}{8} & \multirow{2}{*}{3.84} & \multirow{2}{*}{2.71} & \multirow{2}{*}{2.94} & $A_{s}=1.02$ & $A_{s}=1.24$ \\
\hline & & & & & $A_{s}=1.23$ & $A_{s}=1.31$ \\
\hline \multirow{2}{*}{$\mathrm{L} 2$} & \multirow{2}{*}{8} & \multirow{2}{*}{3.84} & \multirow{2}{*}{2.44} & \multirow{2}{*}{1.79} & $A_{s}=0.92$ & $A_{s}=0.90$ \\
\hline & & & & & $A_{s}=1.23$ & $A_{s}=1.23$ \\
\hline \multirow{2}{*}{ L3 } & 8 & 384 & 464 & 358 & $A_{s}=2.19$ & $A_{s}=1.92$ \\
\hline & & & 4.04 & & $A_{s}=2.23$ & $A_{s}=1.95$ \\
\hline L4 & 8 & 3.84 & 3.76 & 3.12 & $A_{s}=1.75$ & $A_{s}=1.36$ \\
\hline & & & 5.10 & & $A_{s}=1.95$ & $A_{s}=1.40$ \\
\hline
\end{tabular}

Source: The authors, (2016). 


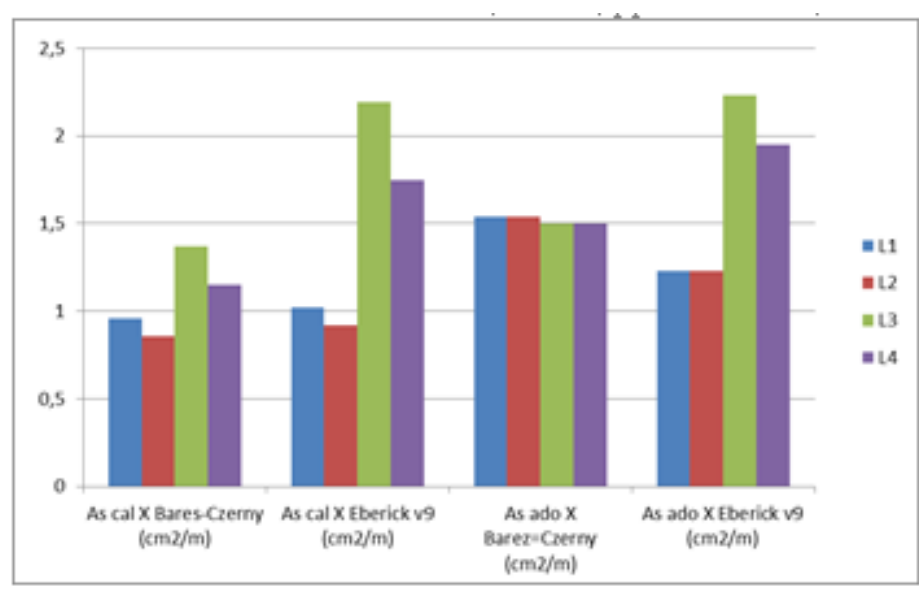

Figure 24. Chart: Steel area comparative $\left(A_{s}\right)$ calculated and adopted between Bares-Czerny theory and Eberick $v 9$ in the direction of X.

Source: The authors, (2016)).

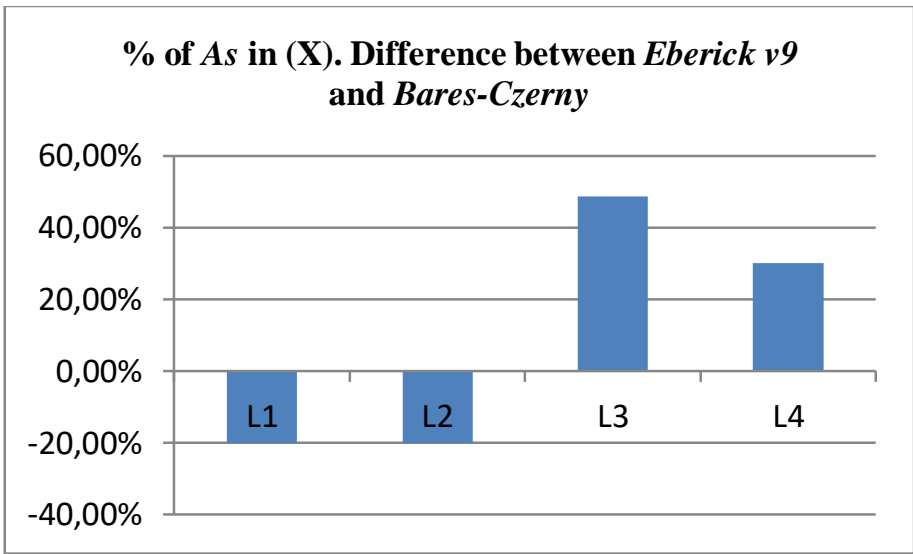

Figure 25. Chart: Percentage difference between the Eberick $v 9$ and Bares-Czerny theory in the direction of $\mathrm{X}$.

Source: The authors, (2016).

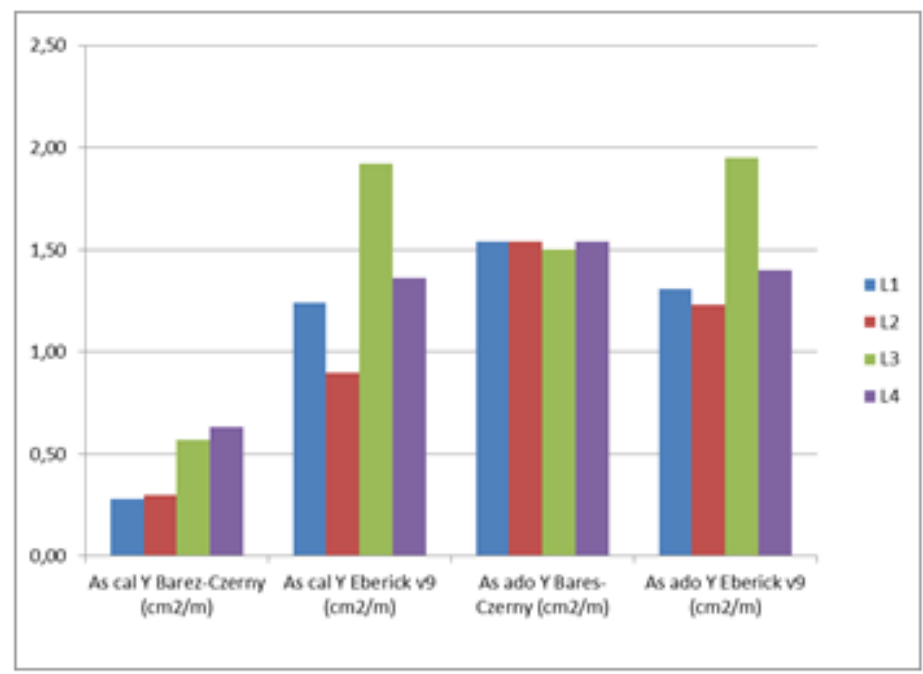

Figure 26. Chart: Steel area comparative $\left(A_{s}\right)$ calculated and adopted between Bares-Czerny theory and Eberick $v 9$ in the direction of Y.

Source: The authors, (2016).

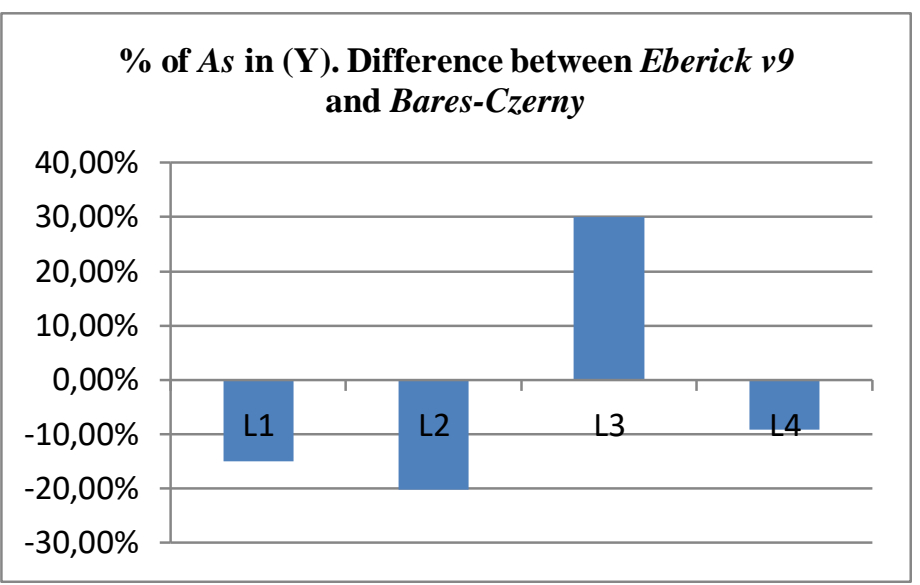

Figure 27. Chart: Percentage difference between the Eberick $v 9$ and Bares-Czerny theory in the direction of $\mathrm{Y}$.

Source: The authors, (2016).

\section{IV. $3 A_{S}^{\prime}$ SLABS RESULTS AS BARES-CZERNY AND EBERICK V9}

By the methods applied for the proposed dimensioning, presented in table 4 final results of $\left(A_{s}^{\prime}\right)$, as well as the final figures for the negative bending moments. We also present the comparison in percentage terms of use of such armor between methods, as table 5 and chart the figure 28 .

Table 4: $A^{\prime}{ }_{s}$ results as theory Bares-Czerny and Eberick v9.

\begin{tabular}{|c|c|c|c|c|c|}
\hline \multicolumn{6}{|c|}{$A$ 's results for sizing of the slabs as Bares-Czerny } \\
\hline \multicolumn{4}{|c|}{ Date } & \multicolumn{2}{|c|}{ Results } \\
\hline Beam & Stretch & $\begin{array}{c}\text { Slab } \\
1 \\
\end{array}$ & $\begin{array}{c}\text { Slab } \\
2 \\
\end{array}$ & $\begin{array}{c}\text { Md } \\
\text { kN.m/m }\end{array}$ & $\begin{array}{l}A_{s}{ }_{s} \operatorname{cal}\left(\mathrm{cm}^{2}\right) \\
A_{S} \text { ado }\left(\mathrm{cm}^{2}\right)\end{array}$ \\
\hline V5 & 2 & L1 & L2 & -4.64 & $\begin{array}{l}A^{\prime}{ }_{s}=2.07 \\
A^{\prime}{ }_{s}=2.10\end{array}$ \\
\hline $\mathrm{V} 2$ & 1 & L1 & L3 & -5.59 & $\begin{array}{l}A^{\prime}{ }_{s}=2.52 \\
A^{\prime}{ }_{s}=2.52\end{array}$ \\
\hline $\mathrm{V} 2$ & 2 & L2 & L4 & -5.42 & $\begin{array}{l}A^{\prime}{ }_{s}=2.46 \\
A^{\prime}=2.52\end{array}$ \\
\hline V5 & 1 & L3 & L4 & -7.23 & $\begin{array}{l}A^{\prime}{ }_{s}=3.31 \\
A^{\prime}=3.33\end{array}$ \\
\hline
\end{tabular}

$\mathrm{A}^{\prime}{ }_{\mathrm{s}}$ results for sizing of the slabs as Eberick v9.

\begin{tabular}{c|c|c|c|c|c}
\hline \multicolumn{5}{c|}{ Date } & \multicolumn{2}{c}{ Results } \\
\hline Beam & Stretch & $\begin{array}{c}\text { Slab } \\
\mathbf{1}\end{array}$ & $\begin{array}{c}\text { Slab } \\
\mathbf{2}\end{array}$ & $\begin{array}{c}\text { Md } \\
(\mathbf{k N . m} / \mathbf{m})\end{array}$ & $\begin{array}{c}\boldsymbol{A}^{\prime}{ }_{s} \mathbf{c a l}\left(\mathbf{c m}^{2}\right) \\
\boldsymbol{A}^{\prime}{ }_{s} \text { ado }\left(\mathbf{c m}^{2}\right)\end{array}$ \\
\hline V5 & 2 & L1 & L2 & -5.54 & $\begin{array}{c}A^{\prime}{ }_{s}=2.66 \\
{ }^{\prime}{ }_{s}=2.83\end{array}$ \\
\hline V2 & 1 & L1 & L3 & -6.04 & $A^{\prime}{ }_{s}=2.91$ \\
\hline V2 & 2 & L2 & L4 & -5.62 & $\begin{array}{c}A^{\prime}{ }_{s}=3.12 \\
{ }^{\prime}{ }_{s}=2.69\end{array}$ \\
\hline V5 & 1 & L3 & L4 & -7.95 & $\begin{array}{c}A^{\prime}{ }_{s}=4.04 \\
A^{\prime}=4.19\end{array}$ \\
\hline
\end{tabular}

Source: The authors, (2016). 
Table 5: $A_{s}^{\prime}$ increase of percentage between Eberick $v 9$ and BaresCzerny theory.

\begin{tabular}{|c|c|c|c|c|c|}
\hline \multirow{2}{*}{ Slabs } & \multicolumn{6}{|c|}{$\begin{array}{c}\text { Bares-Czerny } \\
\text { theory }\end{array}$} & \multicolumn{2}{c|}{ Eberick v9 } & $\begin{array}{c}\text { Difference } \\
\text { \% }\end{array}$ \\
\cline { 2 - 6 } & $A^{\prime}$ ' Cal & $A^{\prime}$ 's Ado & $A^{\prime}$ 's Cal & $A^{\prime}$ 's Ado & \\
\hline L1 - L2 & 2,07 & 2,10 & 2,66 & 2,83 & $34,76 \%$ \\
\hline L1 - L3 & 2,52 & 2,52 & 2,92 & 3,12 & $23,81 \%$ \\
\hline L2 - L4 & 2,46 & 2,52 & 2,69 & 2,83 & $12,30 \%$ \\
\hline L3 - L4 & 3,31 & 3,33 & 4,04 & 4,19 & $25,83 \%$ \\
\hline
\end{tabular}

Source: The authors, (2016).

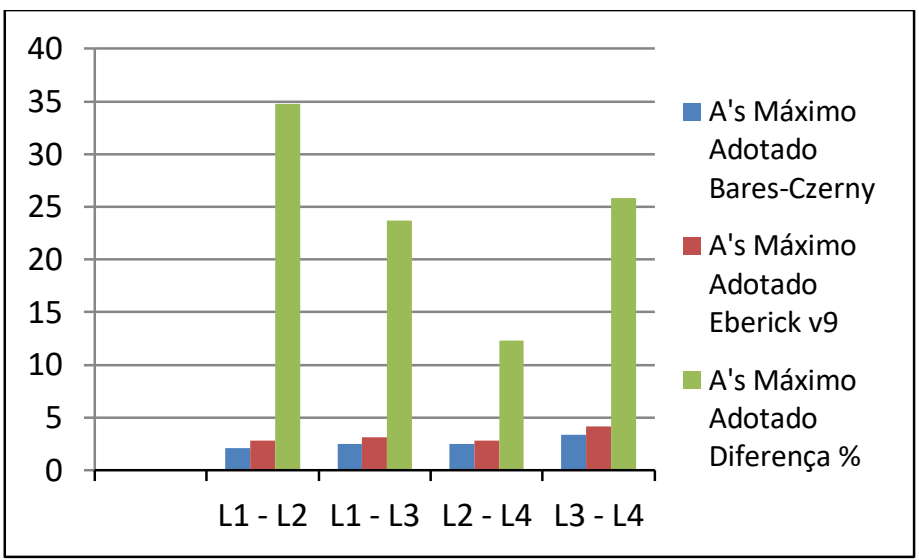

Figure 28. Chart: \% Difference $A_{s}^{\prime}$ adopted between Eberick $v 9$ and Bares-Czerny theory.

Source: The authors, (2016).

\section{IV.4 COMPARISON OF HEIGHTS AND LOADS AS BARES- CZERNY AND EBERICK V9}

After analyzing the results obtained in item 4.1, is allowed to observe the data presented in tables and graphs the figure 22 to 23 that with use of Eberick $v 9$ tool there is a $20 \%$ reduction in concrete consumption and, $11,52 \%$ on the charges that apply slabs on the building. This is due to the fact that, in the design of slabs using the tables of Bares-Czerny theory, takes in all the slabs of the building the maximum height (h) of $10 \mathrm{~cm}$ found in slabs L3 and L4. Thus contributing to an increase in the consumption of concrete and loads compared to the design with use of Eberick $v 9$ tool. In this case, it is observed that with the use of the Bares-Czerny theory, there is an increase in the own weight of the structure and the overloads foundations. Consequently, there is a need to scale up shoes larger to absorb the increased loads, thereby contributing to high cost in implementing the building.

\section{IV.5 COMPARISON OF POSITIVE ARMORS $\left(A_{S}\right)$ AS BARES- CZERNY AND EBERICK V9}

Continuing the discussion of the results obtained in IV.2, we analyzed the data presented in Table 3 and 3 to graphics the figure 25 carry out the comparison of positive reinforcement $\left(A_{s}\right)$ in the $\mathrm{X}$ direction, as proposed in specific objectives. Therefore, based on the data presented in table and cited above graphic, we found that with the use of Eberick $v 9$ tool, there is a reduction in the consumption of positive reinforcement of the L1 and L2 slabs in the direction of $\mathrm{X}$, however, there is an increase of those armor for the slabs L3 and L4. Remember that this increase does not mean high cost of construction due to the photo that it is fully offset by savings of $20 \%$ in specific consumption, as described in item IV.4. For evaluation of positive reinforcement (As) in the Y direction, results found in section IV.2 and shown in table 3 and graphs da figure 26 to 27 graphs that the reduction in consumption of such armor is much higher therefore this reduction occurs for slabs L1, L2 and L4 and L3 only slab is observed that increased steel consumption. Remember that, for the same reason stated above in section IV.4 and IV.5, the increase in positive reinforcement (As) the slab L3 in the direction of Y does not mean higher costs for running the building.

\section{IV.6 COMPARISON OF NEGATIVE ARMOR $\left(A^{\prime} S\right)$ AS BARES- CZERNY AND EBERICK $V 9$}

Continuing the discussion of the results obtained in 4.3 is allowed to observe the tables 3 to 4 and graphs the figure 28 that with the use of Eberick $v 9$ tool there is an increase in the consumption of negative reinforcement $\left(A_{s}^{\prime}\right)$ compared the same armor found in the method using the Bares-Czerny theory.

This increase is of the order of $34,76 \%$ for the negative reinforcement that occur between the slab L1-L2, and $23,81 \%$ for the same armor occurring between the slabs L1-L3. L2-L4 between the slabs is $12,30 \%$ and the same armor occurring between the slabs L3-L4 is $25,83 \%$, according to the results presented in Table 5 of item IV.3.

However again worth noting that the increase of these armor does not mean increased cost for running the building for the same reason explained above in items IV.4 and IV.

\section{CONCLUSION}

This work presented a structural sizing methodology for determining cross-sectional area of longitudinal reinforcement tensile (The) positive and (A's) negative massive slabs of residential building roof deck by the theoretical method of BaresCzerny and using computational tool Eberick v9, in order to perform the comparison of the results $\left(A_{s}\right.$ and $\left.A_{s}^{\prime}\right)$ obtained. We conclude that both methods meet the proposed objectives.

However, we note that the main advantage obtained in using Bares-Czerny theory to the measurement $\left(A_{s}\right.$ and $\left.A_{s}^{\prime}\right)$ is that design engineers apply throughout the method the fundamental concepts of structural analysis such as: equilibrium conditions, types of bonds, states and stability, among others, as well as policy recommendations. However it has the disadvantage of making very robust construction, applying higher loads to the foundations and therefore increasing the construction costs, in addition to being less effective in terms of structural dimensioning production time.

Moreover the use of Eberick v9 computational tool for the proposed dimensioning makes it possible to design more slender structures by applying smaller loads to the foundations, producing excellent projects much smaller time and causing the project hour costs are drastically reduced. Additionally enables better analysis of the projected structure. It presents however the disadvantage that any electronic tool has, that is, of not being intelligent (standalone), requiring the designer's expertise, which must not simply rely on the results of the tool and never despise their own knowledge. As a 
further step to this work, we intend to study the behavior of structural elements of the building under study, in order to enrich the topics covered, providing the basis of information/consultation to all interested parties on topics related either.

\section{ACKNOWLEDGMENTS}

UNINORTE Laureate International Universities, for research support.

\section{REFERENCES}

[1]PORTO, T.M.B.; FERNANDES, D.S.G.F. Curso Básico de Concreto Armado Conforme NBR 6118/2014 . São Paulo: Oficina de Textos, 2015. 264 p.

[2]BOTELHO, M.H.C.; MARCHETTI, O. Concreto Armado Eu te Amo. 8. Ed. São Paulo: Blucher, 2013. 533 p.

[3]ASSOCIAÇÃO BRASILEIRA DE NORMAS TÉCNICAS. NBR 6118: Projetos de estruturas de concreto - Procedimento. Rio de Janeiro, 2014. 256 p.

[4] NBR 7480: Aço destinado à armaduras para estruturas de concreto armado - Especificação. Rio de Janeiro, 2007. 17 p.

[5]FERREIRA, S.L. Da Engenharia Simultânea ao Modelo de Informações de Construções (BIM). Contribuição das ferramentas ao processo de projeto e vice-versa. Workshop Brasileiro de Gestão do Processo de Projeto na Construção de Edifícios. Curitiba: 2007. 189 p.

[6]SOUZA, A.C.; et all. Auto CAD 2004 Guia Prático para Desenhos em 2D. Florianópolis: Ufsc, 2005. 167 p.

[7]MORI, R. Documentação Técnica Eberick v9. Florianópolis: 2014. 357 p.

[8]LEMES, I.J.M., et al., Determinação da capacidade resistente de elementos estruturais mistos através do método da rótula plástica refinado. Revista Internacional de Métodos Numéricos para Cálculo y Disenõ en Ingeniería. Ouro Preto, 2015. Disponível em:

$<$

http://www.sciencedirect.com/science/article/pii/S021313151500 0656 > Acessado em: 30 set. 2016.

[9]BASTOS, P.S.S. Lajes de Concreto: Notas de aula da disciplina Estrutura de Concreto I. Universidade Estadual Paulista. Faculdade de Engenharia, Departamento de Engenharia Civil. Bauru: 2015. 119 p.

[10]NBR 6123: Forças devidas ao vento em edificações. Rio de Janeiro, 2010. 66 p.

[11]CARVALHO, R.C.; PINHEIRO, L.M. Cálculo e Detalhamento de Estruturas Usuais de Concreto Armado. 2. Ed. São São Paulo: Pini, 2013. 617 p.

[12] NBR 6122: Projeto e execução de fundações. Rio de Janeiro, 2010. 103p.
[13]NBR 6120: Cargas para o cálculo de estrutura de edificações. Rio de Janeiro, 1980. 16 p. 